\title{
Atmospheric salt deposition in a tropical mountain rainforest at the eastern Andean slopes of south Ecuador - Pacific or Atlantic origin?
}

\author{
Sandro Makowski Giannoni ${ }^{1}$, Katja Trachte ${ }^{1}$, Ruetger Rollenbeck ${ }^{1}$, Lukas Lehnert ${ }^{1}$, Julia Fuchs ${ }^{2}$, and Joerg Bendix ${ }^{1}$ \\ ${ }^{1}$ Laboratory for Climatology and Remote Sensing (LCRS), Institute of Physical Geography, Department of Geography, \\ Philipps-Universitaet, Marburg, Germany \\ ${ }^{2}$ Laboratory of Climatology, Institute of Physical Geography, Department of Geography, \\ Ruhr-Universitaet, Bochum, Germany
}

Correspondence to: Sandro Makowski Giannoni (makowsks@ students.uni-marburg.de)

Received: 17 June 2015 - Published in Atmos. Chem. Phys. Discuss.: 8 October 2015

Revised: 10 July 2016 - Accepted: 13 July 2016 - Published: 12 August 2016

\begin{abstract}
Sea salt $(\mathrm{NaCl})$ has recently been proven to be of the utmost importance for ecosystem functioning in Amazon lowland forests because of its impact on herbivory, litter decomposition and, thus, carbon cycling. Sea salt deposition should generally decline as distance from its marine source increases. For the Amazon, a negative east-west gradient of sea salt availability is assumed as a consequence of the barrier effect of the Andes Mountains for Pacific air masses. However, this generalized pattern may not hold for the tropical mountain rainforest in the Andes of southern Ecuador. To analyse sea salt availability, we investigated the deposition of sodium $\left(\mathrm{Na}^{+}\right)$and chloride $\left(\mathrm{Cl}^{-}\right)$, which are good proxies of sea spray aerosol. Because of the complexity of the terrain and related cloud and rain formation processes, sea salt deposition was analysed from both, rain and occult precipitation (OP) along an altitudinal gradient over a period between 2004 and 2009. To assess the influence of easterly and westerly air masses on the deposition of sodium and chloride over southern Ecuador, sea salt aerosol concentration data from the Monitoring Atmospheric Composition and Climate (MACC) reanalysis data set and back-trajectory statistical methods were combined. Our results, based on deposition time series, show a clear difference in the temporal variation of sodium and chloride concentration and $\mathrm{Na}^{+} / \mathrm{Cl}^{-}$ ratio in relation to height and exposure to winds. At higher elevations, sodium and chloride present a higher seasonality and the $\mathrm{Na}^{+} / \mathrm{Cl}^{-}$ratio is closer to that of sea salt. Mediumto long-range sea salt transport exhibited a similar seasonality, which shows the link between our measurements at high elevations and the sea salt synoptic transport. Although the
\end{abstract}

influence of the easterlies was predominant regarding the atmospheric circulation, the statistical analysis of trajectories and hybrid receptor models revealed a stronger impact of the north equatorial Atlantic, Caribbean, and Pacific sea salt sources on the atmospheric sea salt concentration in southern Ecuador. The highest concentration in rain and cloud water was found between September and February when air masses originated from the north equatorial Atlantic, the Caribbean Sea and the equatorial Pacific. Together, these sources accounted for around $82.4 \%$ of the sea salt budget over southern Ecuador.

\section{Introduction}

Poor substrate and intense leaching by precipitation make tropical forests particularly prone to nutrient deficiency. While phosphorus is mainly considered a limitation to net primary productivity (NPP) in lowland Amazonian tropical forests, phosphorus and nitrogen co-limit growth in the tropical mountain rainforests, as in southern Ecuador (Homeier et al., 2012; Koehler et al., 2009; Tanner et al., 1998; Vitousek, 1984; Wolf et al., 2011; Wullaert et al., 2010). Because of a worldwide increase in nitrogen and phosphorus emissions and a pronounced increase in emissions from developing countries, where the majority of tropical forests are located, atmospheric deposition in these countries has gained attention (Dentener et al., 2006; Galloway et al., 2008; Phoenix et al., 2006). 
In several tropical and temperate forests, human intervention in the nitrogen and phosphorus cycles have has been documented (Mahowald et al., 2005; Matson et al., 2002; Phoenix et al., 2006; Tipping et al., 2014; Yu et al., 2015). Because nutrient availability regulates ecosystem processes and functions, the changes currently affecting the nitrogen and phosphorus budgets are expected to have wide-reaching impacts in forest ecosystem structure and diversity (Bobbink et al., 2010; Homeier et al., 2012; Matson et al., 2014; Peñuelas et al., 2013; Pett-Ridge, 2009; Wang et al., 2014; Wilcke et al., 2013). The role of sea salt availability has very recently gained attentions, as it has been found to condition the behaviour of herbivores, in addition to affecting carbon cycling and organic matter decomposition in tropical ecosystems (Dudley et al., 2012; Kaspari et al., 2008, 2009; Powell et al., 2009; Voigt et al., 2008). At the western rim of the Amazon forest, in Peru, Ecuador, and Colombia, there is evidence that herbivorous and frugivorous birds and mammals visit mineral licks to compensate for low sodium concentration in plant and fruit tissues (Lee et al., 2009; Lizcano and Cavelier, 2004; Powell et al., 2009; Voigt et al., 2008). Furthermore, some taxa of arthropod have reportedly begun practicing geophagy to deal with salt scarcity in plants (Kaspari et al., 2008). Yet, despite its pantropical importance, salt availability has hitherto been overlooked in most biogeographic and biogeochemical studies (Dudley et al., 2012).

By far, the most important source of continental sea salt depositions are the oceans. Sea salt scarcity in Amazonian rainwater increases along a gradient from the Atlantic coast towards the Andean range, which acts as a natural orographic barrier to the west. The concentration of both sodium and chloride in rainwater diminishes significantly with increasing distance from the Atlantic Ocean (Talbot et al., 1990). Additionally, the ratio between both concentrations inverts from $\mathrm{Cl}^{-}>\mathrm{Na}^{+}$close to the ocean to $\mathrm{Cl}^{-}<\mathrm{Na}^{+}$far from the ocean (Tardy et al., 2005). Consequently, tropical mountain forests on the eastern slopes of the Andes and tropical lowland forests at the western edge of the Amazon are expected to suffer from sea salt deprivation, whereas forests closer to the Atlantic coast are subject to large sea salt deposition (Dudley et al., 2012).

The tropical mountain forests at the eastern Andean slopes in southern Ecuador may likely represent an exception of this generalized pattern because of their location in the Huancabamba depression, an area where the Andes rarely exceed $3600 \mathrm{~m}$ in altitude. This allows the transport of Pacific air masses rich in sea salt. As a result, the mountain forest might benefit not only from sea salt transported by easterly air masses from the Atlantic but also by sea salt originating from Pacific air masses. Depending on the strength of the contribution to sodium and chloride deposition originating from the Pacific, the combined input from Atlantic and Pacific sources could result in a greater sodium and chloride availability than that found for the lowland forests on the western rim of the Amazon (Dudley et al., 2012).
However, little research has investigated the deposition of atmospheric sodium and chloride in the tropical forests of the southern Ecuadorian Andes. Furthermore, any such research has yet to identify their sources. In this context, an investigation of the deposition by occult precipitation (OP) is particularly important, because OP comprises an extremely high proportion of total precipitation in tropical mountain forests. OP is the water supplied to soil or vegetation by light drizzle, wind-driven, rain and fog and/or clouds that conventional rain gauges cannot measure. An exception is the work of Fabian et al. (2009), who estimated the origin of the local sea salt deposition by visual interpretation of single back trajectories. To our knowledge, neither a comprehensive quantitative investigation on sea salt sources nor any estimates of their contribution to the atmospheric deposition have been conducted yet.

As a consequence of the knowledge gaps regarding the sea salt sources of deposition in the Andes of southeastern Ecuador, the aims of this study are as follows: (1) to characterize sodium and chloride atmospheric deposition by rain and OP along an altitudinal gradient and at different topographic locations in a tropical mountain rainforest site; (2) to identify potential Pacific, Atlantic, and continental geographic sources of sea salt concentration over the Andes of southern Ecuador by applying back-trajectory statistical techniques and reanalysis data of atmospheric composition; and (3) to estimate the contribution of each source area to the atmospheric sea salt concentration in the Andes of southern Ecuador.

\section{Study area}

The study area is located at the northwestern edge of the Amazon basin $\left(4^{\circ} 00^{\prime} \mathrm{S}, 79^{\circ} 05^{\prime} \mathrm{W}\right)$, at the southeastern Andes of Ecuador, approximately a $100 \mathrm{~km}$ straight line distance away from the Pacific coast and around $2000 \mathrm{~km}$ from the closest part of the Atlantic coast (Fig. 1). The study area contains the San Francisco valley, deeply incised into the eastern slope of the main Andes range. Since 2002, two successive multidisciplinary research programs have investigated the Reserva Biológica San Francisco (RBSF), located on the northern slopes of the valley and some areas outside of the reserve (Beck et al., 2008; Bendix et al., 2013).

The Andes in this area are characterized by lower elevations and higher geomorphological complexity compared to other parts of the mountain chain in northern Ecuador, Peru, and Colombia. Since studies have shown that exposure and altitude affect deposition patterns (Griffith et al., 2015; Kirchner et al., 2014; Lovett and Kinsman, 1990; Makowski Giannoni et al., 2013), a precondition for the study of sea salt deposition is to collect measurements along a large altitudinal gradient and at different slope exposures.

The climate of the catchment is mainly determined by the constant tropical easterlies. However, the trade winds 


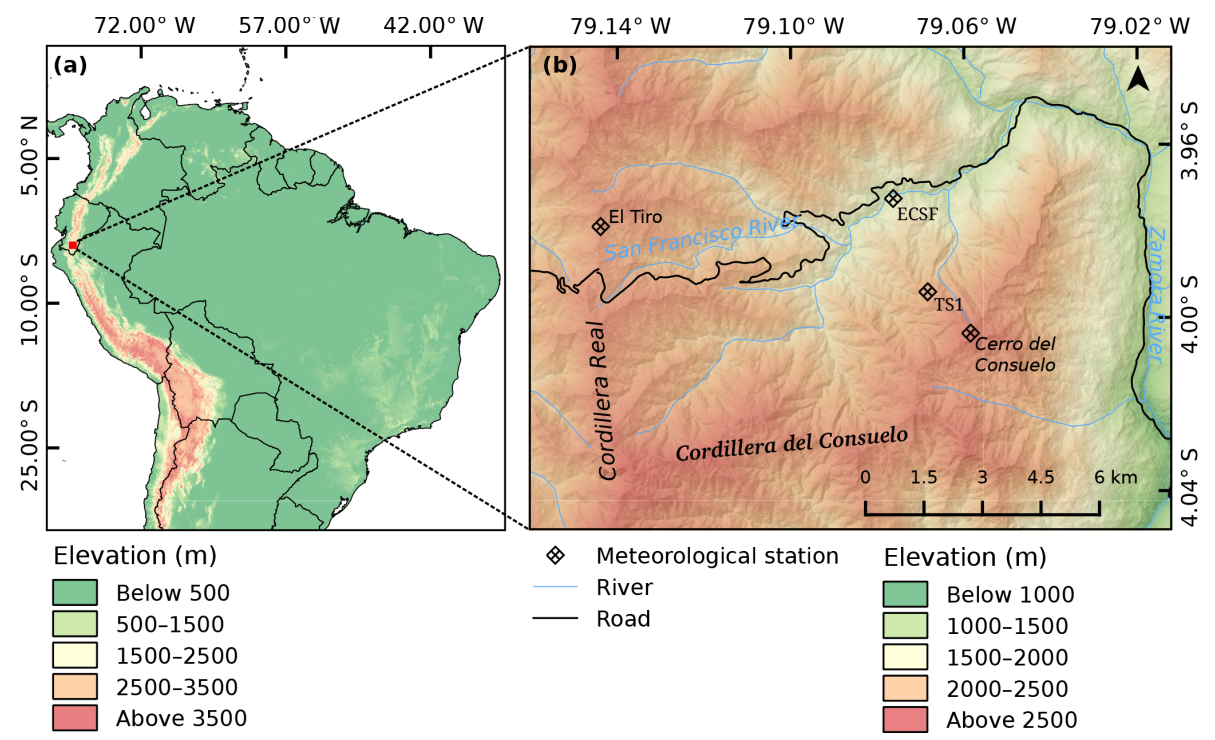

Figure 1. Map of the study area. (a) Location of the study area in the Huancabamba depression of the Andes in South America. (b) Detailed map of the rain and OP sampling sites installed in the study area.

are weakened each year between November and March, and westerly wind bursts occur locally because of the low altitude of the mountains. Those westerly winds are transporting Pacific air masses into the study area (see Fig. 1, Bendix et al., 2008a; Emck, 2007). Precipitation responds to the displacement of the intertropical convergence zone (ITCZ) and the intensity of the tropical easterlies. The highest rainfall occurs between June and August, when the easterly winds predominate, carrying humid air masses from the lowlands of the Amazon. The topography forces the humid air upwards leading to high rainfall totals, especially in the higher parts of the mountains, and the peaks' immersion into the clouds, resulting in OP (Bendix et al., 2006, 2008b; Richter et al., 2013; Rollenbeck et al., 2011). In the period from 2004 to 2009 , average rainfall varied from 1500 to $6500 \mathrm{~mm}$ per year between 1960 and $3180 \mathrm{~m}$. In the highest regions, OP contributes up to $35 \%$ of total precipitation (Rollenbeck et al., 2011). A short dry season occurs between November and March when Pacific air masses are transported to the area by occasional westerlies. Such air masses occur less than $20 \%$ of the time (Richter et al., 2013) and are accompanied by convective activity.

\section{Data and methods}

The methodology is comprised of two components. First, we analyse local salt (sodium and chloride) concentrations by assessing the sodium and chloride concentrations in samples of rain and OP along an altitudinal gradient. To do so, we use a statistical approach due to the complexity of the terrain. Second, we attempt to derive the source of the salt. The second part focuses on describing the transport pathways as- sociated with the general atmospheric circulation patterns to detect potential source areas of sea salt. Our goal is to draw connections between the contributions each respective atmospheric sea salt source has on our study area. Back-trajectory analysis was used to achieve this goal.

\subsection{Sample collection, materials, and data}

Three meteorological stations (MSs) were installed on the north-facing slopes of the San Francisco valley along an altitudinal transect ranging from 1960 to $3180 \mathrm{~m}$ in elevation. A fourth station (El Tiro, $2725 \mathrm{~m}$ ) was installed at a mountain pass about $4 \mathrm{~km}$ up the valley on the Cordillera Real (Fig. 1).

Rain and OP samples were collected at each station between 2004 and 2009. While rain water was collected in totaling gauges (UMS 200, made of polyethylene to warrant chemical inertia), OP was collected in $1 \mathrm{~m}^{2}$ mesh grid fog collectors designed according to Schemenauer and Cereceda's proposal (Schemenauer and Cereceda, 1994). Details about rain and fog measurement techniques, calibration, and data handling are described in Rollenbeck et al. (2007), Fabian et al. (2009), and Rollenbeck et al. (2011).

Rain and OP samples were collected at almost regular weekly intervals. The samples were filtered and immediately stored in frozen state, before being sent to the laboratory for ion analyses. All samples were analysed at the University of Munich's Weihenstephan Center (TUM-WZW) for major ions $\left(\mathrm{K}^{+}, \mathrm{Na}^{+}, \mathrm{NH}_{4}{ }^{+}, \mathrm{Ca}^{2+}, \mathrm{Mg}^{2+}, \mathrm{Cl}^{-}, \mathrm{SO}_{4}{ }^{2-}, \mathrm{NO}_{3}{ }^{-}\right)$. Cations were analysed according to the inductivity-coupled plasma method (Perkin Elmer Optima 3000), while ion chromatography (Dionex DX-210) was used for anions. The detection limits are 0.1 and $0.2 \mathrm{mg} \mathrm{L}^{-1}$ for sodium and chloride, respectively. 
The sea salt mixing ratio of the Monitoring Atmospheric Composition and Climate (MACC) reanalysis data set was used as a proxy for the sea salt concentration in the atmosphere, with a horizontal resolution of $0.75^{\circ}$ by $0.75^{\circ}$ (Inness et al., 2013). In this data set, the concentration of sea salt generated by wind stress on the ocean surface was determined based on a source function developed by Guelle et al. (2001) and Schulz et al. (2004), accounting for sedimentation as well as wet and dry deposition processes. The sea salt concentration was integrated for three size bins $(0.03-$ $0.5,0.5-5.0$, and 5.0-20.0 $\mu \mathrm{m}$ ) and calculated for 60 vertical model levels with the upper model limit at $0.1 \mathrm{hPa}$ (Benedetti et al., 2009; Morcrette et al., 2009). To our knowledge, this is the only available global sea salt concentration data that span the period covered in this study. Furthermore, this reanalysis data set has performed well when compared to measured satellite and ground-based data (Benedetti et al., 2009).

\subsection{Statistical evaluation of sodium and chloride ion concentration in rain and $\mathrm{OP}$}

Since sea spray aerosol consists mainly of chloride and sodium (Millero, 2014), we used the ion concentration of both elements in rain and OP as proxies of sea salt atmospheric inputs into the ecosystem. Because sodium is a conservative ion in sea salt aerosol, it is often used as a reference for sea salt concentration in precipitation chemistry and atmospheric chemistry modelling studies (Jaeglé et al., 2011; Keene et al., 1986; Pozzer et al., 2012; Tardy et al., 2005; Vet et al., 2014). Chloride is more unstable, as it photochemically reacts with other atmospheric ions (e.g. sulfur and nitrogen species), and it is depleted as a function of time spent in the atmosphere (Keene et al., 1986).

Weekly sodium and chloride concentrations in water samples from rain and OP were weighted with the total weekly precipitation volume to calculate volume-weighted monthly mean concentrations (VWMMs). With the calculated VWMMs we compiled monthly time series of sea salt concentration for a 6-year time series from 2004 to 2009, which represented the temporal variation in the concentration at each altitudinal level of the study area. To identify differences in the distribution of sodium and chloride concentrations between the sites, we created boxplots of total concentration over the 6-year evaluated period at each altitudinal level. Additionally, we computed total volume-weighted means (VWMs) to compare our observations with those from other studies.

We analysed the relationship to other ions $\left(\mathrm{K}^{+}, \mathrm{NH}_{4}{ }^{+}\right.$, $\mathrm{Ca}^{2+}, \mathrm{Mg}^{2+}, \mathrm{SO}_{4}{ }^{2-}, \mathrm{NO}_{3}{ }^{-}$) using a principal factor analysis (PFA) to locate common transport histories and the likely origin of sodium and chloride. Before conducting the PFA, the data were normalized and scaled to achieve comparable distributions.

In coastal continental areas, the $\mathrm{Na}^{+} / \mathrm{Cl}^{-}$molar ratio is typically that of sea salt (Keene et al., 1986). This ratio was calculated using the measurements from each altitude and serves as an indicator of the origin of both sodium and chloride concentration in precipitation. The ratio changes as a function of distance from the ocean, as chloride is photochemically depleted in the atmosphere.

Finally, to asses a likely impact of anabatic flows on the sodium and chloride budget, we calculated wind direction relative frequency plots.

\subsection{Back-trajectory and source-receptor analysis}

The HYSPLIT model was used to generate back trajectories of air masses encompassing 10 days with a resolution of 1 day (Draxler and Hess, 1998). Modeling was done using the openair package (Carslaw and Ropkins, 2012) for R statistical language. The wind fields were derived from the ERA-Interim reanalysis (Dee et al., 2011) with a grid resolution of $0.75^{\circ}$ by $0.75^{\circ}$. All trajectories had their origins at the San Francisco River catchment in southern Ecuador. The MACC reanalysis sea salt concentration data were set as proxy of sea salt concentration in the atmosphere for airmass transport analysis by back-trajectory techniques. To test the link between the MACC sea salt concentration and the sodium and chloride concentrations actually measured in rain and OP, both were linearly correlated. Pearson's productmoment correlation coefficients were calculated between the concentration at the two uppermost MSs (El Tiro and Cerro del Consuelo) and the MACC sea salt concentration (see Table 1). Based on the correlation coefficients, the MACC data set at $700 \mathrm{hPa}$ and the medium particle size $(0.5-5.0 \mu \mathrm{m})$ was chosen as the input parameter for further examination by back-trajectory analysis, because it yielded the highest correlation coefficient and significance level.

Given the spatial resolution of the data set $\left(0.75^{\circ}\right.$ by $\left.0.75^{\circ}\right)$, the outcome of this analysis can only provide evidence of synoptic transport pathways and source-receptor relationships for medium- to long-distance sources for an area of approximately 80 by $80 \mathrm{~km}^{2}$ in the southern Ecuadorian Andes. Local-scale transport is not represented by the used trajectory models.

We first aimed to identify the potential geographic origin of the sea salt concentration over this wider area covering our receptor site in southern Ecuador. For this particular purpose we used source-receptor modelling, as it has been successfully applied to determine likely geographic origins of pollutants and aerosols (e.g. Fleming et al., 2012; Hsu et al., 2003; Powell et al., 2009; Riuttanen et al., 2013; Robinson et al., 2011). Here, two different hybrid receptor models were used for comparison: the potential source contribution function (PSCF) and the adjusted concentration-weighted trajectory (CWT) running on a grid that covers the domain of the 2192 generated trajectories between 2004 and 2009. Given the high seasonality of synoptic air mass transport, we calculated the models on a seasonal basis (Bendix et al., 2008a; Emck, 2007). 
Table 1. Results from the correlation analysis between sea salt monthly mean concentration from the MACC reanalysis data and $\mathrm{Na}^{+}$and $\mathrm{Cl}^{-}$monthly mean concentration samples from El Tiro and Cerro del Consuelo meteorological stations. Correlations were tested for the various elevations within the MACC data set.

\begin{tabular}{|c|c|c|c|c|c|c|c|c|c|}
\hline & \multicolumn{3}{|c|}{$\operatorname{MACC} 1(0.03-0.5 \mu \mathrm{m})$} & \multicolumn{3}{|c|}{$\operatorname{MACC} 2(0.5-5 \mu \mathrm{m})$} & \multicolumn{3}{|c|}{ MACC3 $(5-20 \mu \mathrm{m})$} \\
\hline & $\mathrm{Cl}^{-}$ & $\mathrm{Na}^{+}$ & Mean & $\mathrm{Cl}^{-}$ & $\mathrm{Na}^{+}$ & Mean & $\mathrm{Cl}^{-}$ & $\mathrm{Na}^{+}$ & Mean \\
\hline \multicolumn{10}{|c|}{ Cerro del Consuelo } \\
\hline $700 \mathrm{hPa}$ & $0-.36 * *$ & $0.35 * *$ & 0.18 & $0.52 * * *$ & $0.52 * * *$ & $0.40 * * *$ & $0.48 * * *$ & $0.47 * * *$ & $0.52 * * *$ \\
\hline $600 \mathrm{hPa}$ & $0.31 * *$ & $0.26^{*}$ & 0.1 & $0.50 * * *$ & $0.47 * * *$ & $0.39 * *$ & $0.36^{* *}$ & $0.30 *$ & $0.40 * * *$ \\
\hline $500 \mathrm{hPa}$ & $0.27 *$ & 0.19 & 0.03 & $0.47 * * *$ & $0.36 * *$ & $0.30 *$ & 0.22 & 0.13 & $0.28 *$ \\
\hline $400 \mathrm{hPa}$ & $0.24 *$ & 0.19 & 0.03 & $0.37 * *$ & $0.27 *$ & 0.23 & 0.08 & 0.02 & 0.17 \\
\hline $300 \mathrm{hPa}$ & 0.11 & 0.02 & -0.05 & $0.25^{*}$ & 0.16 & 0.23 & 0.01 & -0.05 & 0.14 \\
\hline $200 \mathrm{hPa}$ & 0.22 & 0.09 & 0.03 & $0.30 *$ & 0.18 & $0.25 *$ & -0.02 & -0.04 & 0.08 \\
\hline \multicolumn{10}{|l|}{ El Tiro } \\
\hline $700 \mathrm{hPa}$ & $0.34 * *$ & 0.18 & 0.18 & $0.41 * * *$ & 0.17 & 0.2 & $0.32 * *$ & 0.05 & 0.16 \\
\hline $600 \mathrm{hPa}$ & $0.37 * *$ & 0.22 & 0.2 & $0.40 * * *$ & 0.14 & 0.18 & 0.19 & -0.08 & 0.07 \\
\hline $500 \mathrm{hPa}$ & $0.33 * *$ & 0.18 & 0.16 & $0.31 * *$ & 0.05 & 0.09 & 0.02 & -0.15 & -0.04 \\
\hline $400 \mathrm{hPa}$ & $0.24 *$ & 0.14 & 0.12 & 0.14 & -0.02 & 0 & -0.14 & -0.16 & -0.12 \\
\hline $300 \mathrm{hPa}$ & 0.14 & 0.15 & 0.1 & -0.01 & -0.08 & -0.05 & -0.21 & -0.15 & -0.13 \\
\hline $200 \mathrm{hPa}$ & 0.15 & 0.15 & 0.19 & -0.01 & -0.12 & 0.01 & -0.17 & 0.01 & -0.04 \\
\hline
\end{tabular}

Note: $* p<0.05 . * * p<0.01 . * * * p<0.001$.

The PSCF (Malm et al., 1986; Pekney et al., 2006; Zeng and Hopke, 1989) calculates the probability that a source of aerosol or pollutant observed at the ground measurement site is located at a specific cell in the geographic space and is defined by

$\operatorname{PSCF}_{i j}=\frac{m_{i j}}{n_{i j}}$,

where $n_{i j}$ is the number of trajectory points that passed through cell $(i, j)$ and $m_{i j}$ is the number of times that trajectory points passing through the cell $(i, j)$, and correspond to a high sea salt concentration (above an arbitrary threshold) at the time of the trajectory's arrival at the receptor site. The function is based on the premise that, if a source is located at that specific location, the air masses represented by the trajectory passing through the collocated cell are likely to collect and transport the material along the trajectory until the receptor site. In this study, we defined two concentration thresholds: the 75th percentile for moderate-to-high concentration and the 90th percentile for high concentration.

The adjusted CWT function uses a grid domain to calculate a grid-wise logarithmic mean concentration of an aerosol or pollutant (Seibert et al., 1994) and is defined by

$\ln \left(\bar{C}_{i j}\right)=\frac{1}{\sum_{k=1}^{N} t_{i j}} \sum_{k=1}^{N} \ln \left(\bar{C}_{k}\right) t_{i j k}$,

where $i$ and $j$ are the grid indices, $k$ the trajectory index, $N$ the total number of trajectories, $\bar{C}_{k}$ the pollutant concentra- tion measured upon arrival of trajectory $k$, and $t_{i j k}$ the residence time of trajectory $k$ in grid cell $(i, j)$. In this method, a weighted concentration is assigned to each pixel in the domain. This concentration is the average of the sample concentrations at a given receptor that have associated trajectories crossing the respective cell.

In a second step, we assessed the contribution of the main transport pathways of sea salt to the observed concentration over southern Ecuador. For this purpose, we integrated the MACC sea salt data to the back-trajectory cluster analysis. As for the source-receptor modelling approach, cluster analysis was applied on a seasonal basis to group similar air mass histories. This revealed general circulation patterns and, subsequently, enabled to post-process concentration data in relation to cluster origin and pathways. A partitioning algorithm based on spherical $k$ means was used to define the appropriate number of trajectory clusters, as well as prior knowledge of the main wind systems affecting the receptor site. We tested different $k$ values and chose the maximum number of cluster objects (i.e. back trajectories) that most closely reproduced the known conditions. The cosine distance was used as measure of similarity/dissimilarity between different trajectories. Afterwards, the frequency of trajectories represented by each cluster was determined.

To estimate the contribution of the different seasonal transport pathways to the observed sea salt concentration, the single trajectories belonging to each cluster object (cluster mean trajectory) were related to the sea salt concentration in the nearest neighbouring pixel within the study area. In this way, the contribution of each cluster object to the sea salt con- 
centration above the study site could be statistically evaluated. Likewise, to analyse sources and sinks of sea salt along the cluster mean trajectories, we extracted the mean seasonal concentration values from the MACC data pixels (from 2004 to 2009) that matched the cluster mean trajectories in location, time, and height. Seasonal sea salt concentrations maps were calculated to further interpret the concentration along the cluster mean trajectories. For this, the MACC sea salt data were vertically integrated between $875 \mathrm{hPa}$ (the minimum height of the trajectory clusters) and $500 \mathrm{hPa}$ (maximum height). Additionally, based on findings by Akagi et al. (2011) showing that burning biomass is a contributor to chloride emissions, the Copernicus atmosphere monitoring system's (CAMS) global fire assimilation system (GFAS) (Kaiser et al., 2012) was used to create seasonal maps of $\mathrm{NO}_{x}$ biomass burning fluxes over South America. To estimate the $\mathrm{Na}^{+}$and $\mathrm{Cl}^{-}$contribution from the biomass-burning aerosol mass, we calculated the $\mathrm{Na}^{+}$and $\mathrm{Cl}^{-}$mass ratio to $\mathrm{NO}_{x}$ based on emission factors from Ferek et al. (1998). In this way, seasonal fractions of biomass-burning $\mathrm{Na}$ and $\mathrm{Cl}$ relative to sea salt were calculated.

\section{Results}

\subsection{Sodium and chloride concentration}

Our study area is characterized by the complex topography of the Andes (see Fig. 1). Hence, temporal variation and distribution is of interest in our study of sodium and chloride concentrations in rain and OP at different altitudes and topographical locations.

Figure 2 (left column) depicts the time series of sodium and chloride concentrations at different altitudes. Cerro del Consuelo MS, situated at $3180 \mathrm{~m}$, demonstrated the clearest temporal pattern in concentration, where the highest peaks occurred almost regularly between September and February (Fig. 2a). The highest concentrations of sodium were recorded at Cerro del Consuelo and El Tiro (2825 m) (Fig. 2a and b). Contrarily, chloride concentration peaks in OP were highest at the lowest MS, Estación Científica San Francisco (ECSF) (Fig. 2d).

To compare the respective distributions, the boxplots in Fig. 2 (right column) show the concentration of sodium and chloride for both rain and OP at every MS. Overall, no essential variations between the concentration at each MS could be observed except for chloride in OP and rainwater at ECSF (Fig. 2d), where reported values were much higher than those measured at other elevations. Regarding ion concentration in sodium and chloride species, a clear difference could be observed with chloride concentration in the interquartile range extending between 0.22 and $0.51 \mathrm{mg} \mathrm{L}^{-1}$, and sodium concentration extending between 0.06 and $0.20 \mathrm{mg} \mathrm{L}^{-1}$.

In rainwater samples, the concentrations of chloride were considerably higher than those of sodium at each MS. A larger range and higher extreme values were observed in the chloride concentration. Differences in sodium concentrations between MSs at different altitudes were negligible. The concentrations showed a slight increase at transect 1 (TS1) (median of $0.14 \mathrm{mg} \mathrm{L}^{-1}$ ) and El Tiro (median of $0.13 \mathrm{mg} \mathrm{L}^{-1}$ ) and decreased again at the highest station, Cerro del Consuelo (median of $0.07 \mathrm{mg} \mathrm{L}^{-1}$ ). Compared to the rain samples, OP contained a higher mean concentration of sodium and chloride but also a greater range in its distribution (Fig. 2, left column). The concentration of chloride was also considerably higher than that of sodium, with the highest mean concentration (median of $0.62 \mathrm{mg} \mathrm{L}^{-1}$ ) at the lowest MS, ECSF. Sodium concentration peaked at El Tiro $\left(0.17 \mathrm{mg} \mathrm{L}^{-1}\right)$. At TS1, the mean concentration was lowest (median $\mathrm{Na}^{+} 0.09 \mathrm{mg} \mathrm{L}^{-1}$ and $\mathrm{Cl}^{-} 0.3 \mathrm{mg} \mathrm{L}^{-1}$ ) increased once again at the highest elevations, El Tiro and Cerro del Consuelo (median $\mathrm{Na}^{+}$between 0.11 and $0.17 \mathrm{mg} \mathrm{L}^{-1}$ and $\mathrm{Cl}^{-}$between 0.33 and $0.35 \mathrm{mg} \mathrm{L}^{-1}$ ).

A PFA of every major ion concentration was conducted to gain insights into the origin of sea salt inputs for each MS (Table 2). This analysis indicated four components that explain the majority of the variability in the data set. The load of sodium and chloride had a considerable bearing on either factor 1 or 2, depending on the altitude and location of the MS, and the precipitation type. These two factors explained at least $29 \%$ of the variability in the system (Table 2).

Sodium and chloride explained the greatest variability in the system's rain samples, except for TS1 $(2660 \mathrm{~m})$.

At Cerro del Consuelo, sodium, chloride, and potassium dominated the variability in rain, given that they loaded to factor 1. In OP samples, biomass-burning compounds such as nitrate, sulfate, and ammonium had a stronger signal, loading to factor 1 . Factor 2 was loaded by sodium and chloride only. No other compounds loaded to this factor, meaning that sodium and chloride most likely originated in sea salt from Atlantic and Pacific air masses.

At El Tiro, sea salt sources were exclusively present in factor 1 for rain and factor 2 for OP, similar to Cerro del Consuelo. As for Cerro del Consuelo, sea salt explained most of the variance in rain, followed by biomass-burning compounds. The opposite was true for OP, where biomassburning compounds dominated, followed by sea salt.

The situation at TS1 was more complex than at Cerro del Consuelo and El Tiro, given the combined influence of the local mountain-valley breeze system and the synoptic system. In rain, biomass-burning compounds dominated the variability, with significant loadings on factor 1 . Factor 2 was only loaded with sodium and chloride. In OP, factor 1 represented sea salt and crustal material, as sodium, chloride, and calcium loaded to this factor.

In the rain samples at ECSF, sodium and chloride loaded to factor 1 together with $\mathrm{K}^{+}$. In the OP samples nitrate, $\mathrm{SO}_{4}{ }^{-}$, and $\mathrm{K}^{+}$dominated the variability loading to factor 1 , while sodium and chloride loaded to factor 2 . 
(a)

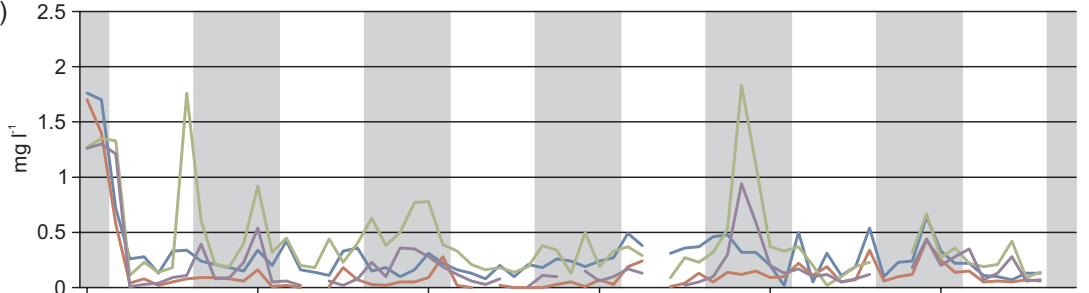

(b)
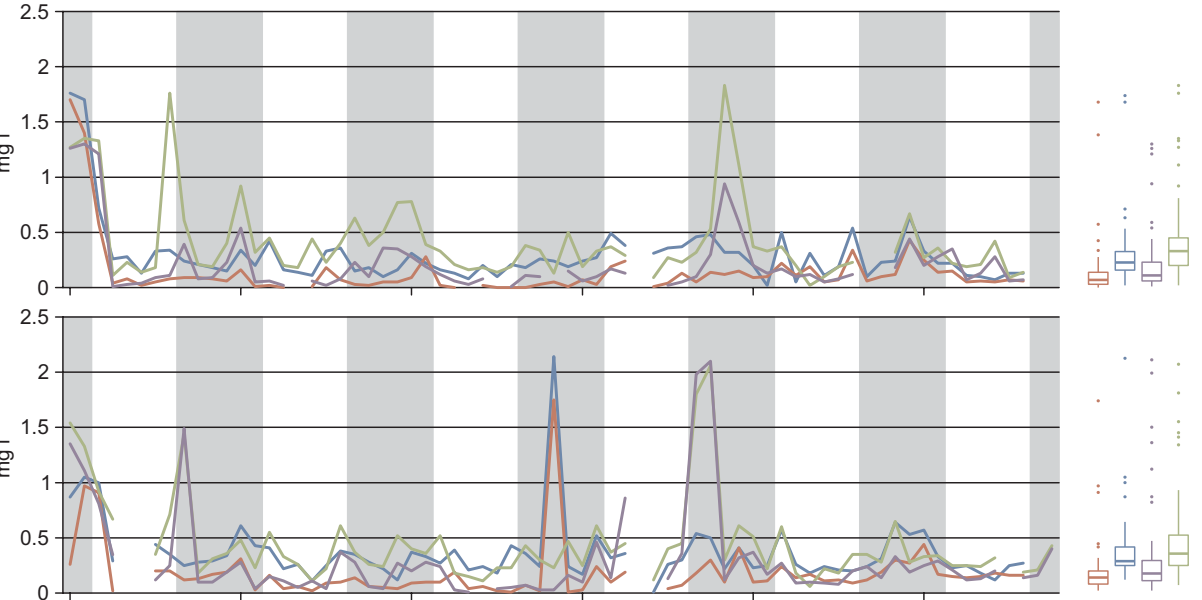

(c)
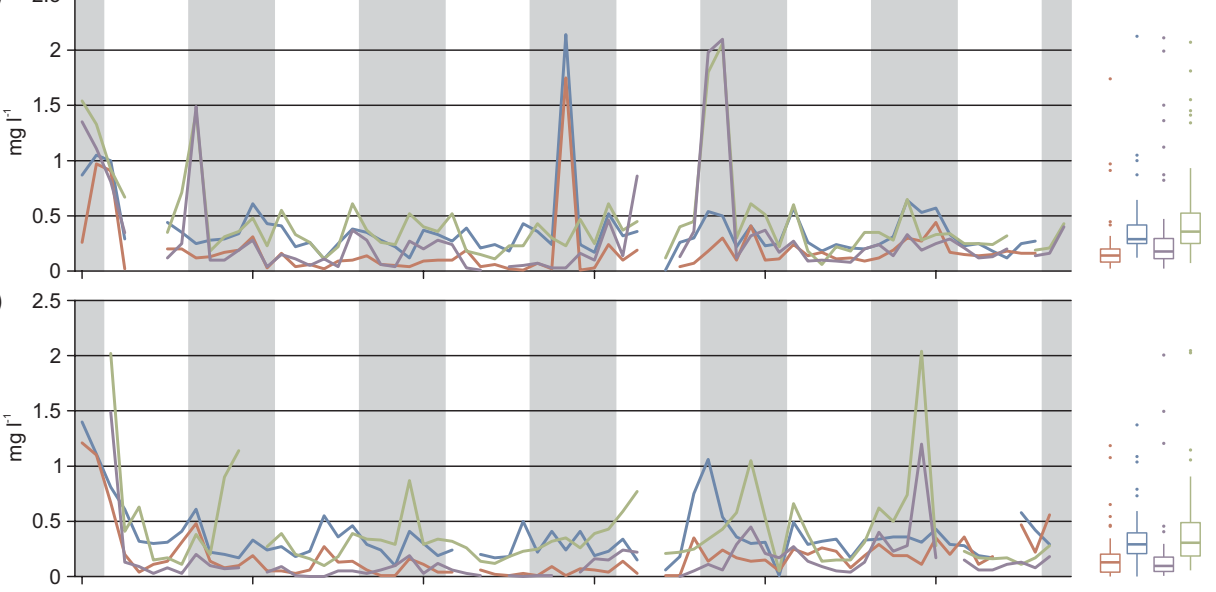

(d)
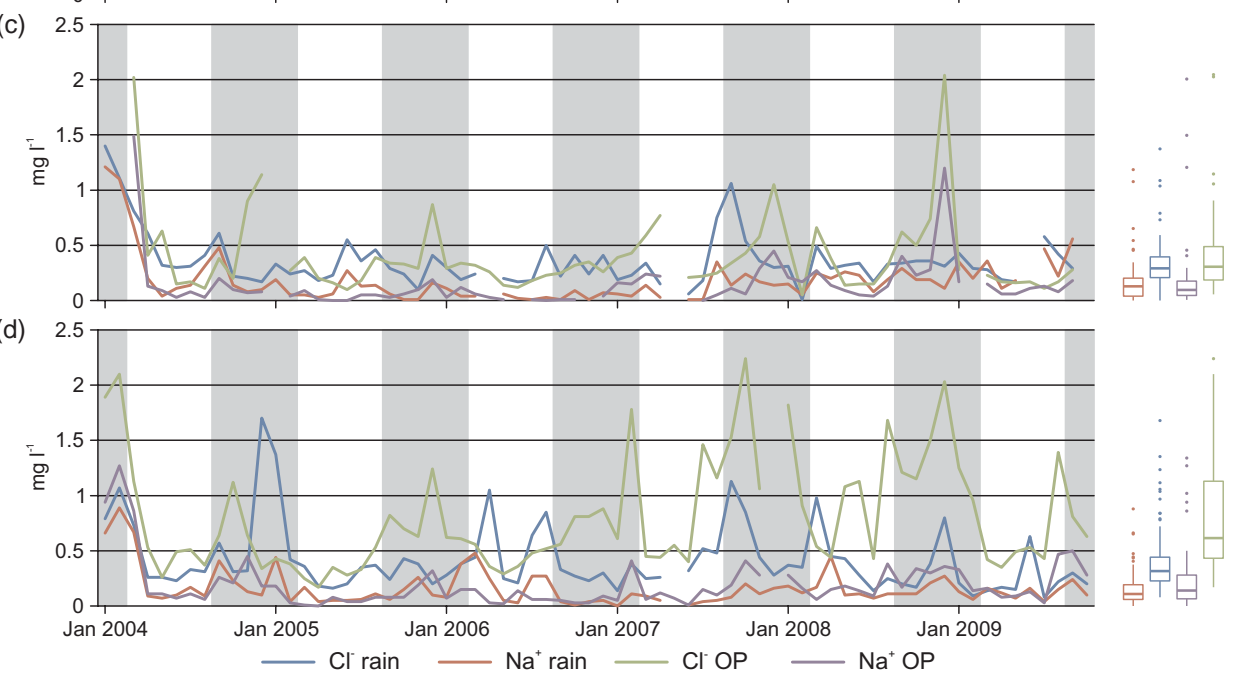

Figure 2. Time series of $\mathrm{Na}^{+}$and $\mathrm{Cl}^{-}$VWMM concentration in rain and OP. These samples come from MSs at different altitudes and topographical locations: (a) Cerro del Consuelo $(3180 \mathrm{~m})$, (b) El Tiro $(2825 \mathrm{~m})$, (c) TS1 (2660 m), and (d) ECSF (1960 m). The shaded areas cover 6-month periods from September to February. The boxplots in the right column show the distribution of each time series: boxes symbolize the lower and upper quartile of the data, vertical lines show ranges of observed concentration, and points are outliers.

Figure 3a shows the $\mathrm{Na}^{+} / \mathrm{Cl}^{-}$molar ratio calculated in data from OP and rain water samples collected at each MS along the altitudinal gradient studied. The typical molar $\mathrm{Na}^{+} / \mathrm{Cl}^{-}$ratio in precipitation for areas close to the sea is 0.86 (dotted line in the figure), according to Keene et al. (1986). The International Co-operative Programme on Assessment and Monitoring of Air Pollution Effects on Forests (ICP) recommends an acceptable range of values between 0.5 and 1.5 molar units (Clarke et al., 2010) (dashed line in Fig. 3). Outliers were likely due to samples with concentrations too close to the detection limits. When approaching the lower limits of the concentration, the ratio becomes more unstable and tends towards more extreme values.

The highest stations show a stronger marine influence, particularly in OP. The ratio fluctuates within the acceptable range and is mostly close to the standard value of sea salt in precipitation from coastal areas. This influence diminishes as the altitude decreases, especially for OP. Median ratios of 0.7, 0.8, 0.5, and 0.3 for Cerro del Consuelo, El Tiro, TS1, and ECSF, respectively, also reflect a greater influence of sea salt at higher altitudes.

A somewhat stronger seasonal behaviour was identified at the two highest stations (grey columns show the period from September to February, with the highest frequency of intrusion by the easterlies). Figure $3 b$ depicts the frequency of trajectories on a yearly basis. In the first 3 years (20042006) the occurrence of westerlies was more frequent and at the same time the $\mathrm{Na}^{+} / \mathrm{Cl}^{-}$ratio was close to that of fresh sea water (local Pacific influence). During 2007-2009, when easterlies were more frequent, the $\mathrm{Na}^{+} / \mathrm{Cl}^{-}$ratio increased due to the increasing influence of distant Atlantic sources (chloride is depleted during transport) and the likely contribution of forest and agricultural fires (Reid et al., 2004; Akagi et al., 2011). 
Table 2. Loadings from PFA with varimax rotation of major ions in rain and OP samples from Cerro del Consuelo, El Tiro, TS1, and ECSF meteorological stations.

\begin{tabular}{|c|c|c|c|c|c|c|c|c|}
\hline & \multicolumn{4}{|c|}{ Rain } & \multicolumn{4}{|c|}{ OP } \\
\hline & Factor 1 & Factor 2 & Factor 3 & Factor 4 & Factor 1 & Factor 2 & Factor 3 & Factor 4 \\
\hline & \multicolumn{8}{|c|}{ Cerro del Consuelo } \\
\hline $\mathrm{NH}_{4}{ }^{+}$ & 0.05 & 0.14 & 0.81 & 0.00 & 0.88 & 0.09 & 0.15 & 0.08 \\
\hline $\mathrm{Ca}^{2+}$ & 0.05 & 0.08 & -0.04 & 0.73 & 0.17 & 0.30 & 0.60 & 0.60 \\
\hline $\mathrm{Cl}^{-}$ & 0.88 & 0.44 & 0.06 & -0.15 & 0.23 & 0.81 & 0.13 & 0.35 \\
\hline $\mathrm{Mg}^{2+}$ & 0.04 & -0.21 & 0.70 & -0.06 & 0.17 & 0.20 & 0.86 & 0.14 \\
\hline $\mathrm{NO}_{3}{ }^{-}$ & 0.27 & 0.91 & 0.00 & 0.19 & 0.87 & 0.27 & -0.02 & 0.42 \\
\hline $\mathrm{K}^{+}$ & 0.85 & 0.06 & -0.02 & 0.28 & 0.84 & 0.24 & 0.25 & 0.09 \\
\hline $\mathrm{Na}^{+}$ & 0.88 & 0.37 & 0.19 & -0.00 & 0.19 & 0.83 & 0.24 & 0.05 \\
\hline \multirow[t]{2}{*}{$\mathrm{SO}_{4}{ }^{2-}$} & 0.49 & 0.64 & -0.15 & -0.03 & 0.54 & 0.30 & 0.34 & 0.64 \\
\hline & \multicolumn{8}{|c|}{ El Tiro } \\
\hline $\mathrm{NH}_{4}{ }^{+}$ & -0.07 & -0.06 & 0.64 & 0.03 & 0.82 & 0.34 & 0.28 & 0.22 \\
\hline $\mathrm{Ca}^{2+}$ & -0.02 & 0.11 & 0.03 & 0.40 & 0.34 & 0.29 & 0.68 & 0.09 \\
\hline $\mathrm{Cl}^{-}$ & 0.98 & 0.09 & -0.11 & -0.11 & 0.31 & 0.90 & 0.25 & 0.01 \\
\hline $\mathrm{Mg}^{2+}$ & 0.05 & -0.04 & 0.87 & -0.03 & 0.48 & 0.38 & 0.52 & 0.38 \\
\hline $\mathrm{NO}_{3}{ }^{-}$ & -0.06 & 0.80 & -0.18 & 0.20 & 0.81 & 0.38 & 0.38 & 0.08 \\
\hline $\mathrm{K}^{+}$ & 0.15 & 0.42 & 0.35 & -0.38 & 0.85 & 0.30 & 0.39 & 0.02 \\
\hline $\mathrm{Na}^{+}$ & 0.97 & 0.04 & 0.08 & 0.01 & 0.33 & 0.87 & 0.31 & 0.16 \\
\hline \multirow[t]{2}{*}{$\mathrm{SO}_{4}{ }^{2-}$} & 0.13 & 0.84 & -0.00 & 0.08 & 0.61 & 0.32 & 0.63 & -0.02 \\
\hline & \multicolumn{8}{|c|}{ TS1 } \\
\hline $\mathrm{NH}_{4}{ }^{+}$ & -0.04 & 0.05 & 0.59 & 0.27 & 0.03 & 0.12 & 0.09 & 0.68 \\
\hline $\mathrm{Ca}^{2+}$ & -0.06 & -0.16 & -0.02 & 0.04 & 0.67 & 0.23 & 0.37 & 0.21 \\
\hline $\mathrm{Cl}^{-}$ & 0.36 & 0.89 & -0.15 & 0.04 & 0.89 & 0.37 & 0.16 & -0.00 \\
\hline $\mathrm{Mg}^{2+}$ & -0.22 & -0.09 & 0.78 & 0.04 & 0.45 & -0.15 & 0.55 & 0.46 \\
\hline $\mathrm{NO}_{3}{ }^{-}$ & 0.91 & 0.14 & -0.20 & 0.27 & 0.22 & 0.89 & 0.00 & 0.18 \\
\hline $\mathrm{K}^{+}$ & 0.15 & 0.08 & 0.34 & 0.67 & 0.57 & 0.42 & 0.58 & 0.18 \\
\hline $\mathrm{Na}^{+}$ & -0.04 & 0.89 & -0.00 & 0.33 & 0.91 & 0.35 & 0.19 & 0.07 \\
\hline \multirow[t]{2}{*}{$\mathrm{SO}_{4}^{2-}$} & 0.83 & 0.29 & -0.11 & -0.06 & 0.41 & 0.80 & 0.13 & 0.00 \\
\hline & \multicolumn{8}{|c|}{ ECSF } \\
\hline $\mathrm{NH}_{4}{ }^{+}$ & 0.01 & 0.78 & 0.11 & -0.10 & 0.34 & 0.42 & 0.39 & 0.43 \\
\hline $\mathrm{Ca}^{2+}$ & 0.23 & 0.01 & 0.02 & 0.03 & -0.04 & 0.03 & 0.07 & 0.50 \\
\hline $\mathrm{Cl}^{-}$ & 0.49 & -0.23 & 0.04 & 0.30 & 0.31 & 0.77 & 0.34 & 0.32 \\
\hline $\mathrm{Mg}^{2+}$ & -0.10 & 0.54 & -0.59 & 0.09 & 0.05 & 0.33 & 0.73 & 0.23 \\
\hline $\mathrm{NO}_{3}{ }^{-}$ & -0.00 & 0.22 & 0.75 & 0.31 & 0.80 & 0.07 & 0.01 & 0.01 \\
\hline $\mathrm{K}^{+}$ & 0.65 & -0.02 & -0.10 & 0.03 & 0.52 & 0.37 & 0.64 & 0.04 \\
\hline $\mathrm{Na}^{+}$ & 0.80 & 0.02 & 0.15 & 0.22 & 0.13 & 0.79 & 0.25 & -0.02 \\
\hline $\mathrm{SO}_{4}{ }^{2-}$ & 0.24 & -0.07 & 0.17 & 0.73 & 0.77 & 0.29 & 0.27 & -0.03 \\
\hline
\end{tabular}

Locally driven winds, such as thermally induced anabatic winds, can contribute to the transport of local sodium and chloride from the valley to the upper parts of the catchment. In a previous study, however, Makowski Giannoni et al. (2013) showed that anabatic winds do not impact MSs located on mountain tops, where synoptic winds predominate. Figure $4 a$ and $b$ show relative frequencies of the wind direction at ECSF and Cerro del Consuelo, respectively. At the lower altitudes (ECSF) a typical mountain-valley breeze circulation system exists, while at the crest (Cerro del Consuelo) north-easterly wind directions predominated.

\subsection{Spatial allocation of sources and general transport pathways}

In the previous section, we analysed the temporal and altitudinal variation of sodium and chloride concentrations in deposition driven by rain and OP. This section addresses the 
(a)

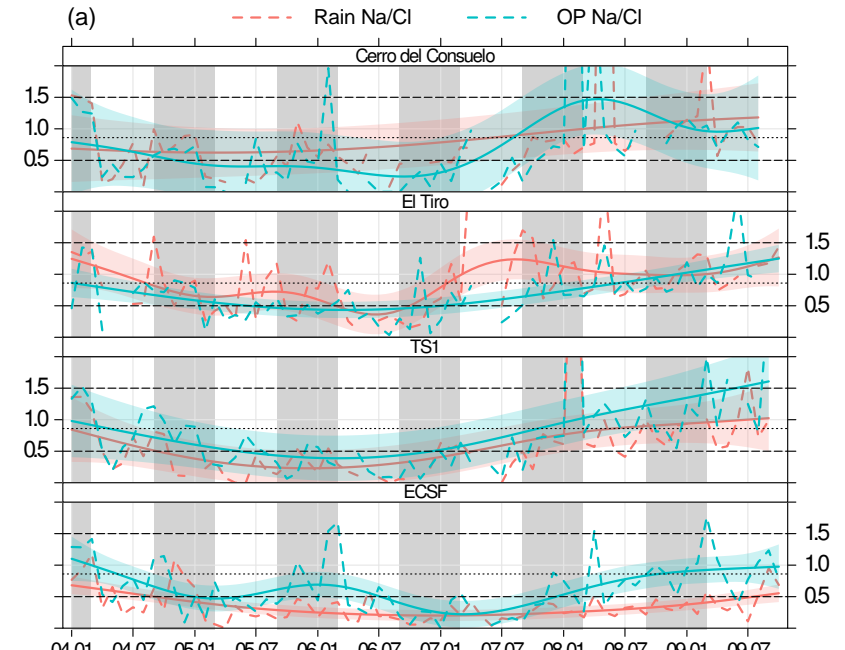

(b)
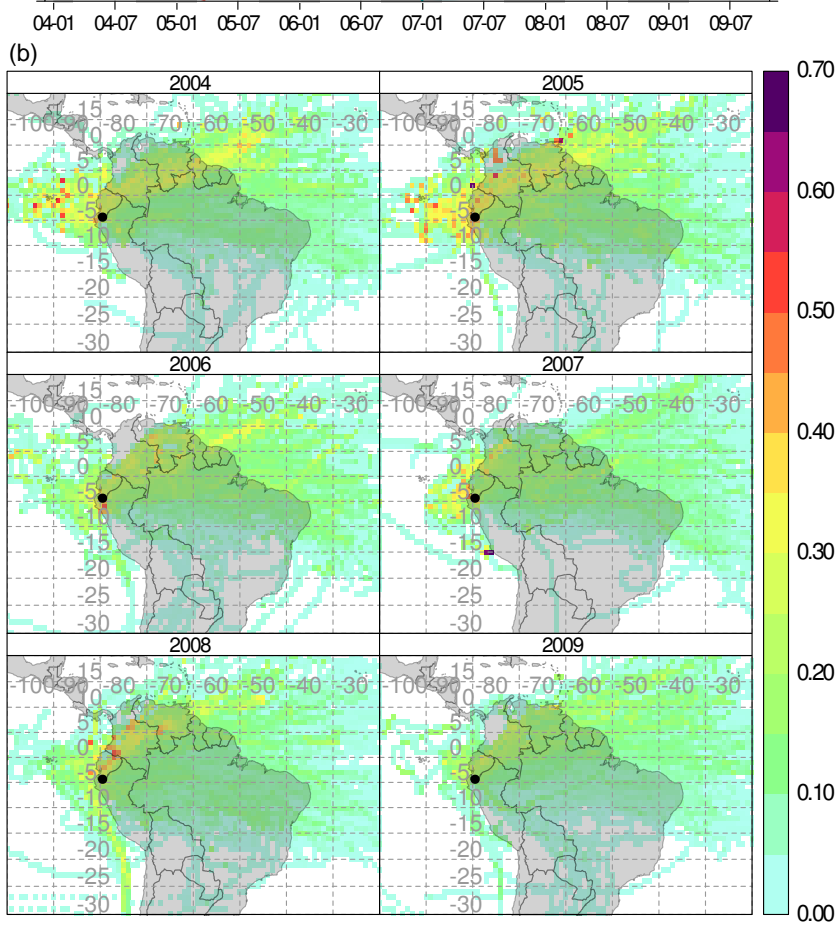

Figure 3. (a) Time series of monthly $\mathrm{Na}^{+} / \mathrm{Cl}^{-}$molar ratios for the four MSs along the altitudinal gradient. Smooth lines are fitted as solid lines and the $95 \%$ confidence interval is shown by the shaded area. (b) Yearly CWT sea salt source maps for southern Ecuador.

remaining question of where the sodium and chloride source areas are located geographically.

The synoptic wind system over South America is driven by strong seasonal circulation patterns. Because the air mass transport to the receptor site is directly linked to the seasonal cycle of the large-scale circulation system (Bendix et al., 2008a; Emck, 2007) and thus, sources of sea salt concentration and their intensity may vary with the seasons, we examined seasonal patterns present in the sources and dominant air mass trajectory clusters.
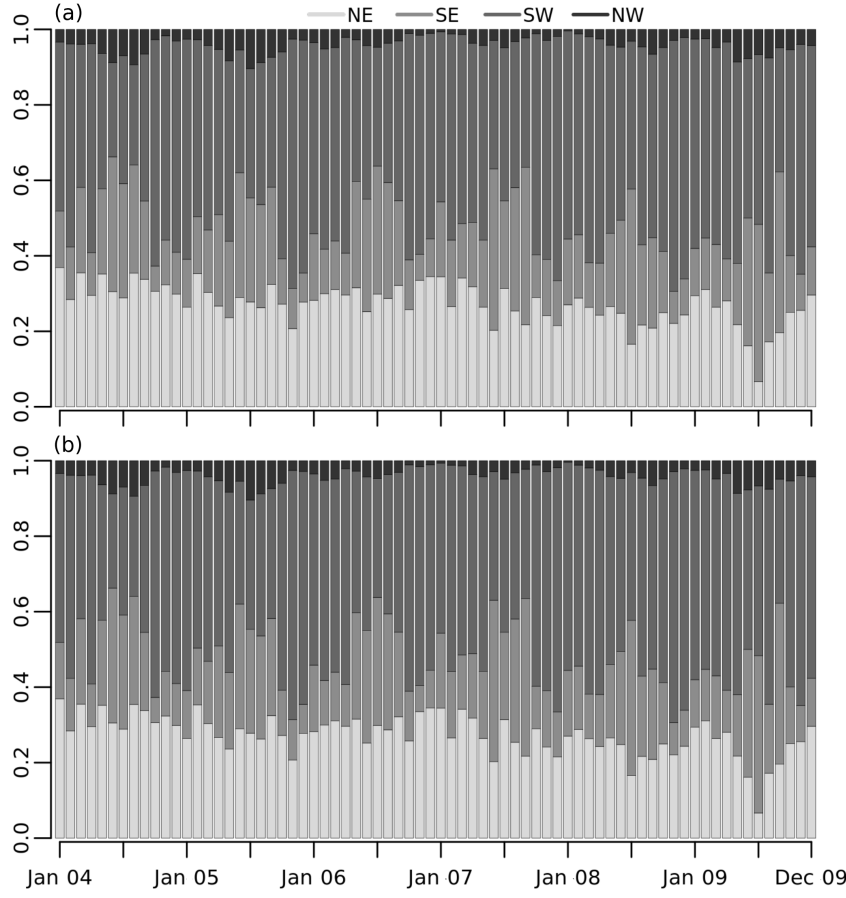

Figure 4. Monthly wind sector relative frequency (\%) for meteorological stations (a) ECSF and (b) Cerro del Consuelo.

We first evaluated potential contributory sources to sea salt concentration at the receptor site for each season. For this purpose, the two hybrid receptor models were used as shown in Fig. 5. In accordance with a sensitivity analysis done with back trajectories starting at different altitudes, these functions were applied to $3180 \mathrm{~m}$, the altitude of the MS Cerro del Consuelo, on top of the highest peak in the catchment. Trajectories starting at lower altitudes have greater uncertainty because local flows are driven by the complex topography and cannot be reproduced. Those starting at higher altitudes provided no further information as they have coincidental source areas.

Figure 5 shows the spatial distribution of potential sources calculated by the PSCF $(a, b)$ and the CWT (c), for DJF, MAM, JJA, and SON at $3180 \mathrm{~m}$ starting height at the receptor. When we compare the spatial distribution of sources between the two models (PSCF and CWT), similar locations in the Atlantic and Pacific oceans are indicated. The highest likelihood (concentrations above $5 e^{-9}$ for Fig. 5a and b and above $5 e^{-9}$ for Fig. 5c) is an equatorial Pacific location, which points to stronger sources of sea salt in that region contributing to the high concentration at the receptor site.

Strong sources of sea salt are expected from either the Pacific or the Atlantic. To judge from the high probability that the concentration stems from the oceans, the results of the PSCF (90th percentile concentration threshold, Fig. 5b) and the CWT (Fig. 5c) performed best in discriminating between potential geographic sources that contributed to mod- 


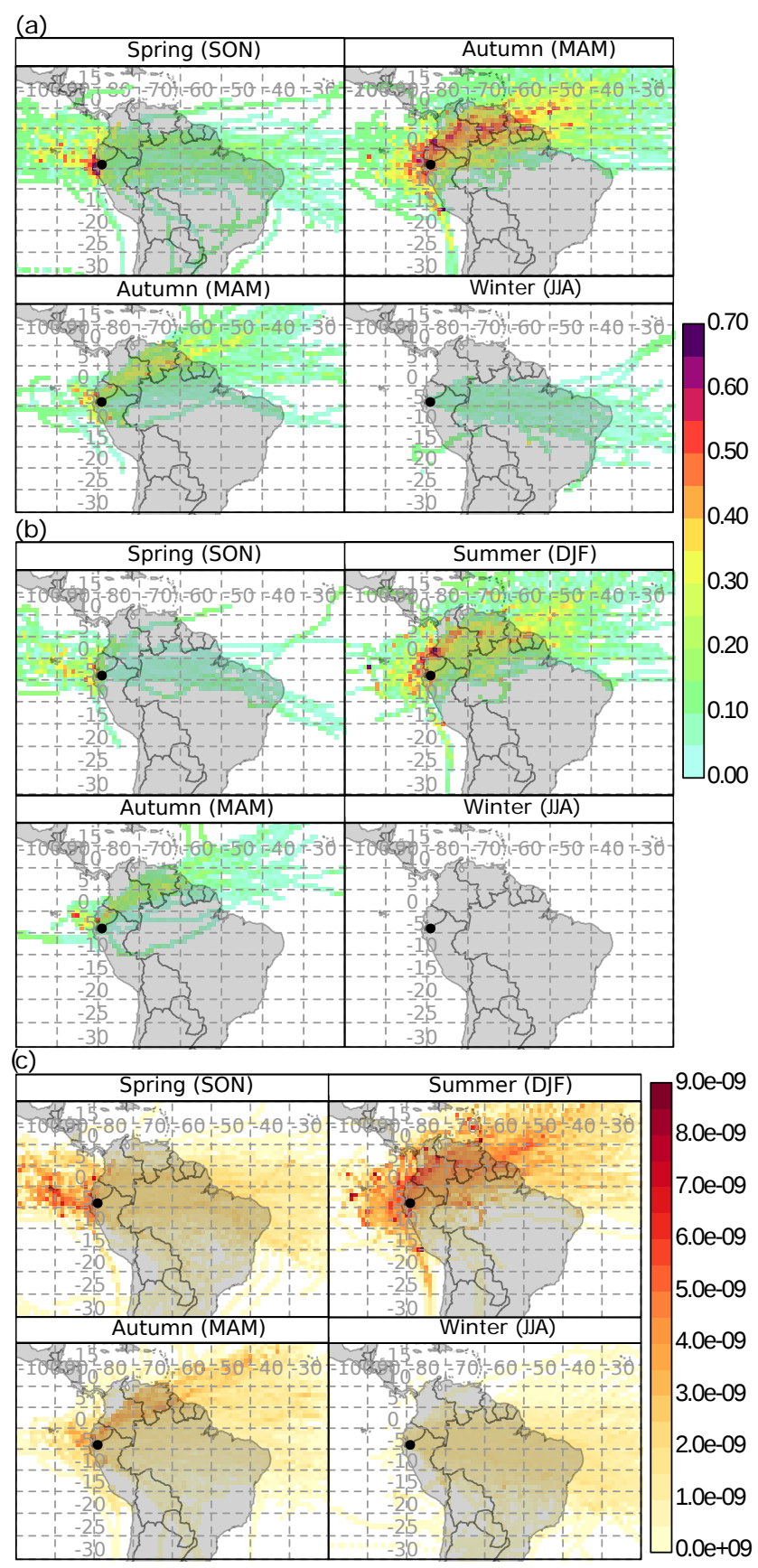

Figure 5. Seasonal sea salt source maps according to (a) PSCF with concentration threshold at 75th percentile, (b) PSCF with concentration threshold at 90th percentile, and (c) CWT; the back trajectory starting height is $3180 \mathrm{~m}$ at the receptor.

erate and high sea salt concentrations over southern Ecuador. In contrast, when using the 75th percentile as the concentration threshold (Fig. 5a) the PSCF only detected the transport pathways for sea salt irrespective of the intensity of the source contribution to the concentration.

Seasonal source contributions that had the greatest impact, i.e. responsible for high sea salt concentrations at the recep- tor site, occurred between September and February (September, October, and November (SON) and December, January, and February (DJF)). During SON, the equatorial Pacific was the dominant source, while in DJF both the Pacific and Atlantic sources contributed to the concentration. Yet, the Pacific sources still appeared stronger, as indicated by the large number of high values in that area. Furthermore, chlorinecontaining compounds related to sea salt and biomass burning were likely co-linearly transported during that season, as shown by the high concentration over the northern portion of South America during DJF, and the coincidence of the biomass-burning season in that area (Fig. 9). On the other hand, during austral autumn (MAM) and winter (JJA) the models identified no relevant potential sources of high sea salt concentration.

After locating the potential geographic sources of sea salt, trajectory cluster analysis was applied to identify the main representative air mass transport patterns, and thus the transport pathways of sea salt (Fig. 6). Here, the easterlies were dominant. In the air mass transport, fast flowing east trajectories dominated (from approximately 83 to $97 \%$ of the trajectories, in DJF and JJA, respectively), and slower-moving trajectories from the west appeared rather sporadically (between approximately 2.8 and $17 \%$ ). The occurrence of bowshaped trajectories was common (Fig. 6, MAM and DJF) and characterized the coastal wind system associated with the Humboldt current (Bendix et al., 2008a; Emck, 2007).

Westerlies mostly evolved during SON and DJF, and to a lesser extent during MAM. Meanwhile, north easterlies were absent during the austral winter (JJA) following the displacement of the ITCZ to the north. The eastern clusters exhibited no seasonal pattern, because they represent the prevailing wind directions throughout the year.

Table 3 summarizes the mean sea salt concentration over southern Ecuador related to each cluster object reaching the receptor site for each season. High concentrations of sea salt are associated with westerly and north-easterly trajectories mainly occurring between September and May (Table 3), whereas easterly air masses that passed over the Atlantic and continental South America before arriving at the receptor site showed intermediate to lower concentrations. In addition to the cluster-associated mean sea salt concentration, values in parenthesis in Table 3 describe the proportion (in percentage) that each cluster contributes to the total concentration during the study period. Cluster $\mathrm{C} 2$, representing the north easterlies, was associated with the highest contributions in DJF and MAM. In SON, cluster C2 represented the easterlies and was likewise associated with the highest contributions. SON is the main biomass-burning season in the Brazilian Amazon, which likely contributed to the overall budget. Furthermore, easterlies' transport from September to May was associated with approximately $75-80 \%$ of the total concentration. The remaining 15-20\% were attributed to air flows passing over the Pacific before reaching the receptor site. These highly loaded seasonal Pacific flows took place in 


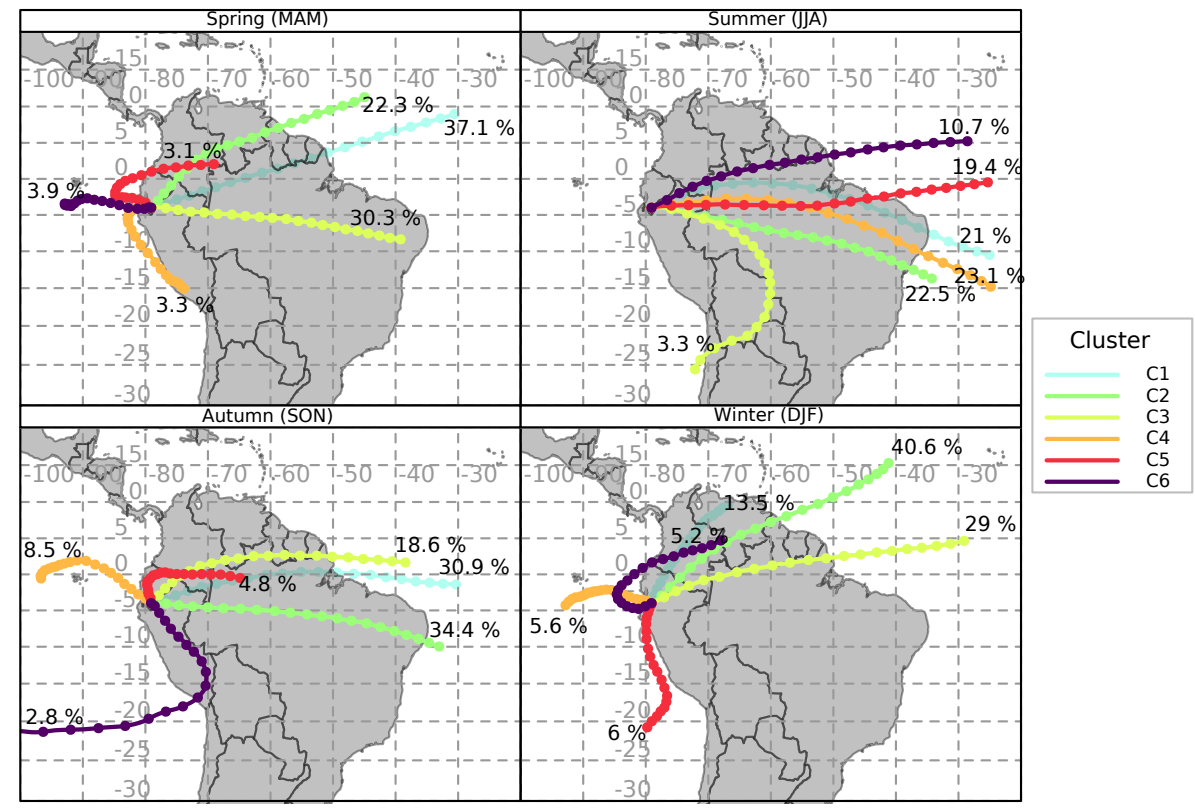

Figure 6. Seasonal mean back-trajectory clusters (C1-C6).

Table 3. Mean sea salt concentration and percentage of total concentration for each season at the receptor site associated to the mean trajectory clusters (C1-C6) in the Andes of southern Ecuador. The percentage contribution of the mean clusters to the total concentration is shown in parenthesis.

\begin{tabular}{lllllll}
\hline & \multicolumn{5}{c}{ Mean sea salt concentration $\left(\mathrm{kg} \mathrm{kg}^{-1}\right)$ and relative total concentration $(\%)$} \\
\hline & C1 & C2 & C3 & C4 & C5 & C6 \\
\hline Summer (DJF) & 5.12E-09(14.42) & $5.18 \mathrm{E}-09(43.76)$ & $3.81 \mathrm{E}-09(22.99)$ & $5.86 \mathrm{E}-09(6.84)$ & $4.57 \mathrm{E}-09(5.7)$ & $5.78 \mathrm{E}-09(6.28)$ \\
Autumn (MAM) & $1.90 \mathrm{E}-09(30.34)$ & $3.80 \mathrm{E}-09(36.42)$ & $1.35 \mathrm{E}-09(17.6)$ & $2.83 \mathrm{E}-09(4.04)$ & $3.85 \mathrm{E}-09(5.18)$ & $3.82 \mathrm{E}-09(6.43)$ \\
Winter (JJA) & $1.72 \mathrm{E}-09(21.28)$ & $1.83 \mathrm{E}-09(24.33)$ & $1.64 \mathrm{E}-09(3.2)$ & $1.53 \mathrm{E}-09(20.83)$ & $1.81 \mathrm{E}-09(20.77)$ & $1.52 \mathrm{E}-09(9.6)$ \\
Spring (SON) & $2.16 \mathrm{E}-09(23.63)$ & $2.33 \mathrm{E}-09(28.36)$ & $2.70 \mathrm{E}-09(17.77)$ & $6.53 \mathrm{E}-09(19.56)$ & $4.18 \mathrm{E}-09(7.07)$ & $3.47 \mathrm{E}-09(3.61)$ \\
\hline
\end{tabular}

the Southern Hemisphere's late spring and summer as easterlies weaken due to the southward shift of the ITCZ. Atlantic air masses contributed to the concentration constantly over the year, also in austral winter (JJA), when the Pacific flows were negligible. However, transport from the Pacific clearly dominated the high peaks at the end and the beginning of each year. The sea salt concentration associated with the easterly clusters was much weaker. However, due to its high frequency, it persistently contributed to the transport from the Atlantic with likely additions from Amazon fires. Similar seasonal patterns were also identified in the measurements as illustrated in Fig. 2, the most clearest of which occurred at the highest station, Cerro del Consuelo (Fig. 2a). That means that the observed patterns in the measurements can be explained by the large-scale atmospheric circulation patterns.

Figure 7 depicts the sea salt concentration along the cluster mean trajectories and the trajectory height for each season. The north equatorial Atlantic was a great source of sea salt during DJF (Fig. 7, column 1), according to the sea salt concentration along the trajectory clusters. Nonetheless, the concentration rapidly decreased as the air masses travelled over the continent. Compared to westerly air masses, easterly air masses were lower in elevation, which increased the probability that they were loaded with aerosols from surface emissions. Those air masses then ascended abruptly as they approached the Andean range. In comparison, the equatorial Pacific is a less significant source for sea salt. Because of its vicinity to the receptor site and because the air masses spent most of the time over the ocean, the concentration did not sink significantly over time (Fig. 7, C4-C6). The concentration peaks in $\mathrm{C} 1$ and $\mathrm{C} 2$ were due to sea salt intrusions from the Caribbean Sea and canalized by the Andean cordillera, as depicted in Fig. 8a. The season DJF was also characterized by frequent forest and agricultural fires in northern South America, which likely contributed chlorinated compounds from biomass burning to the budget as well (Fig. 9). 

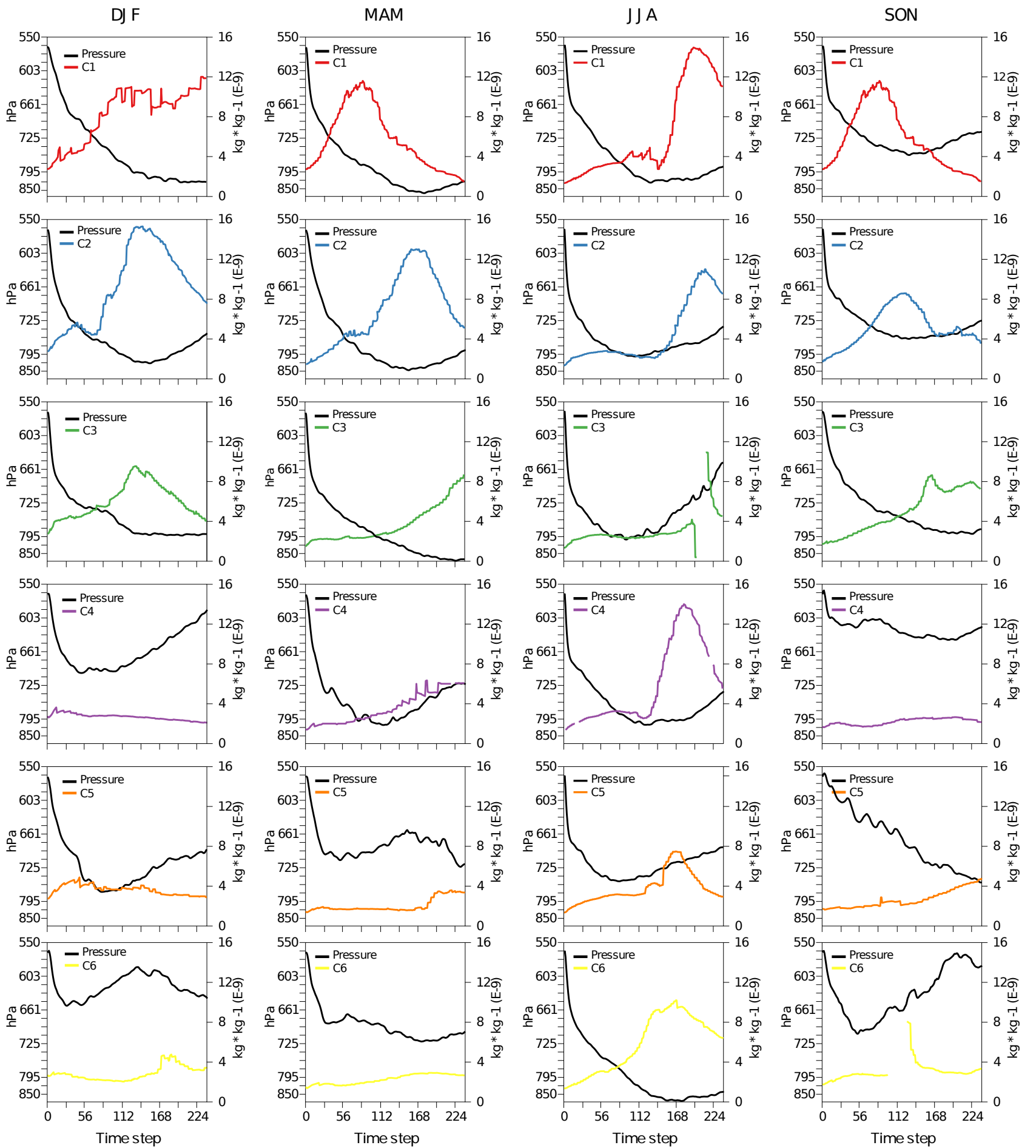

Figure 7. Seasonal plots of sea salt concentration and pressure level along mean back-trajectory clusters. The colours of the sea salt concentration lines match those in the trajectory clusters in Fig. 6. 

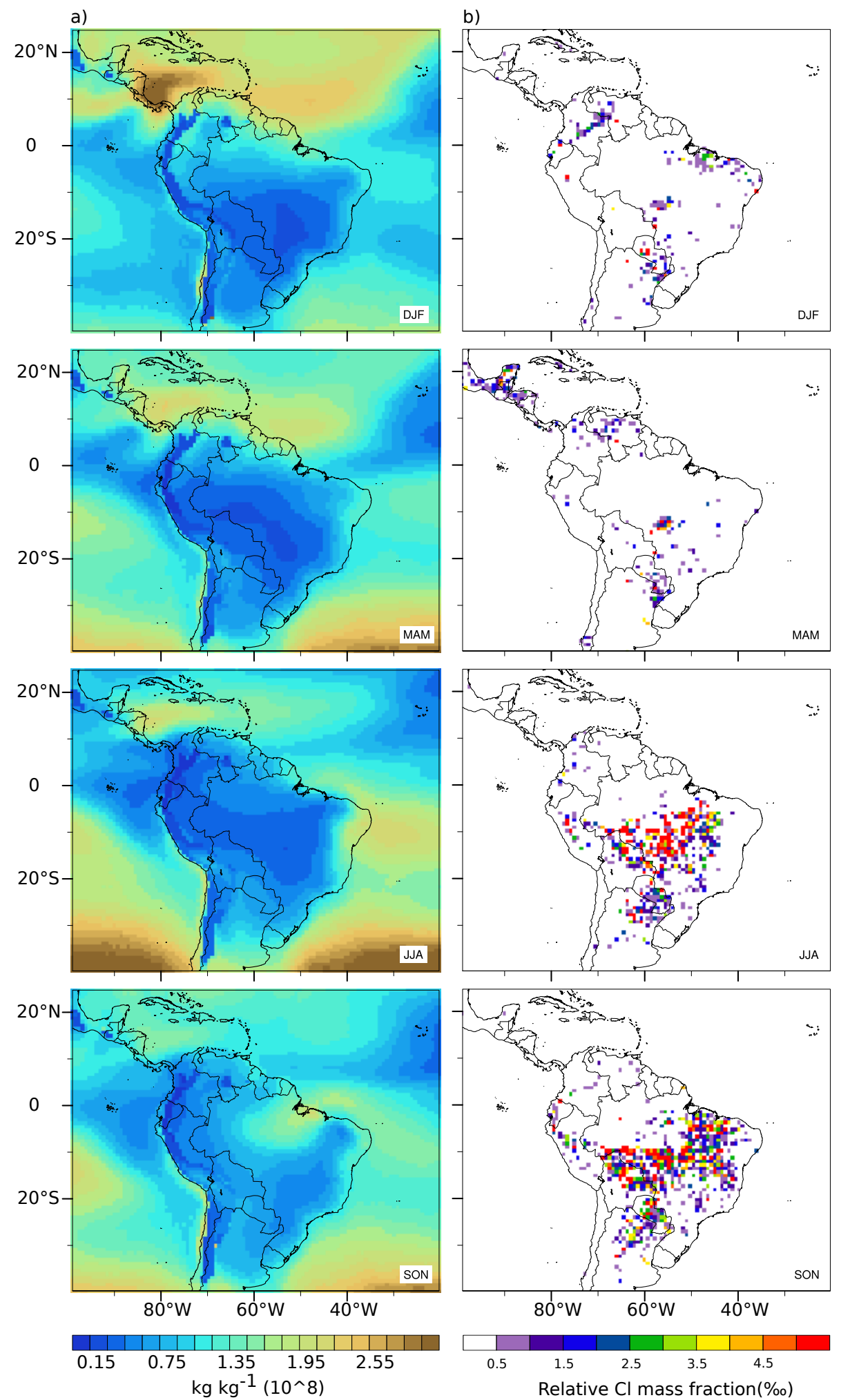

Figure 8. (a) Seasonal maps of sea salt concentration calculated from the MACC reanalysis model. (b) Seasonal maps of biomass-burning $\mathrm{Cl}$ mass fraction relative to sea salt. $\mathrm{Cl}$ mass ratio to $\mathrm{NO}_{x}$ was estimated based on emission factors from Ferek et al. (1998). 

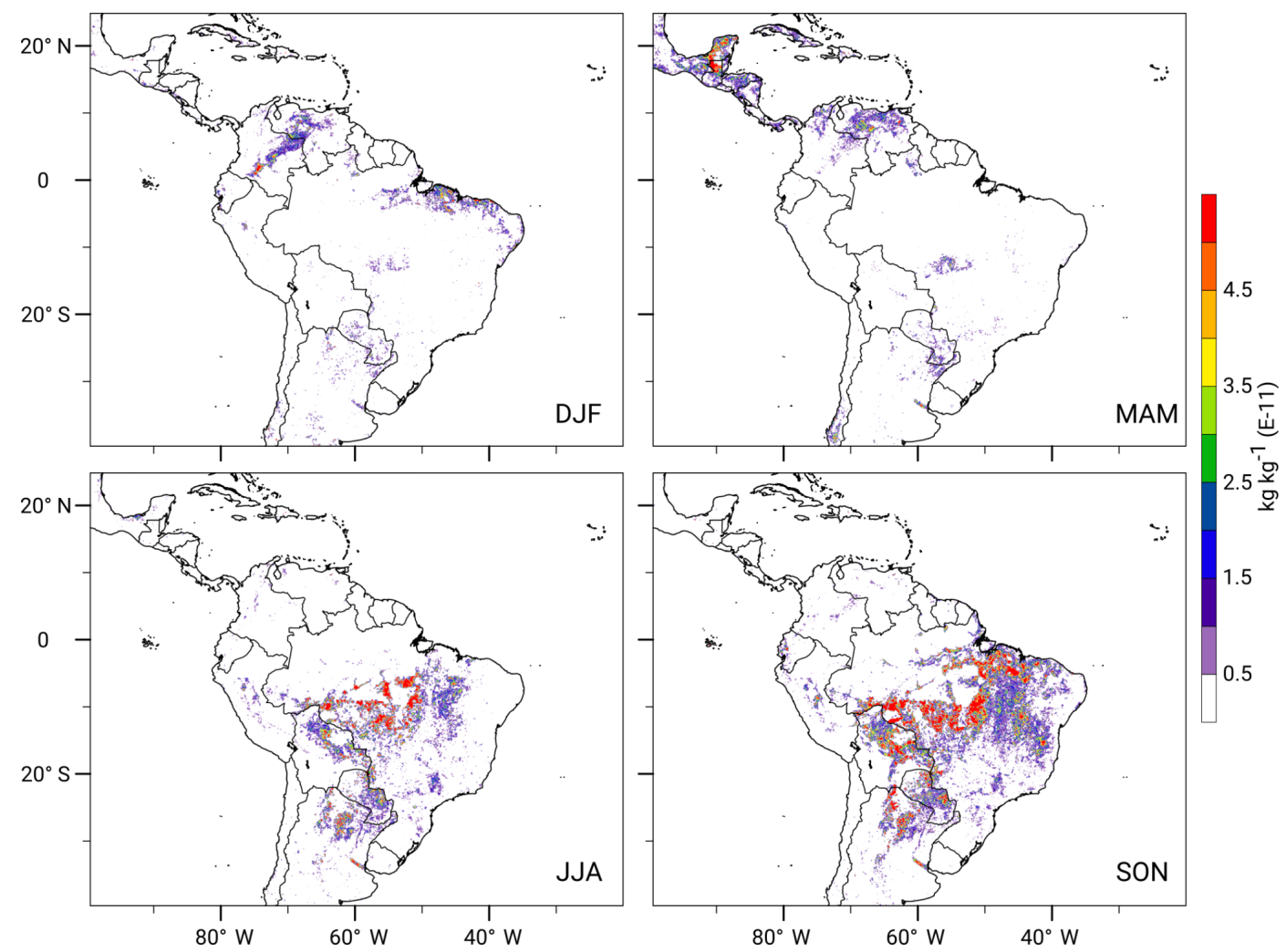

Figure 9. Seasonal maps of $\mathrm{NO}_{x}$ fluxes caused by biomass burning. Values were calculated from the MACC reanalysis model.

A similar situation also occurred in MAM (Fig. 7, column 2), where $\mathrm{C} 1-\mathrm{C} 3$ are north-easterly air masses and $\mathrm{C} 4-\mathrm{C} 6$ represent westerly pathways. In $\mathrm{C} 2$ the intrusion of sea salt from the Caribbean was also present, but less pronounced than in DJF (Fig. 8).

For SON (Fig. 7, column 3) most of the budget was transported from the Atlantic and the continent: clusters $\mathrm{C} 1, \mathrm{C} 2$, and $\mathrm{C} 3$. Because this period coincided with the Brazilian biomass-burning season (see Fig. 9), a considerable quantity of sodium and chloride from the Atlantic (Fig. 8a) and from fire emissions were probably transported to the receptor site.

\section{Discussion}

In this study, we examined potential sources of sodium and chloride for the southern escarpment of the Ecuadorian Andes. The investigation analysed chemical ion concentrations in rain and OP samples along an altitudinal gradient, using back-trajectory statistical analysis and source-receptor modelling.

We first explored the distribution of sodium and chloride inputs by rain and OP in relation to altitude. Overall, comparisons between the MSs reveal a difference in the temporal variation of the concentration of sodium and chloride in rain and OP depending on elevation and exposure. The highest MS, Cerro del Consuelo, displays a distinct seasonal pattern, which is otherwise lacking or less pronounced at the remaining MSs. The largest sodium and chloride concentration occurred between September and February, concomitantly with the southward migration of the ITCZ and the more frequent north easterlies (see Fig. 2).

Chloride was consistently a larger portion of the concentration than sodium, which agrees with findings by Tardy et al. (2005). Their study investigated the chemical composition of rainwater in the Amazon and found that in places closer to the Atlantic Ocean chloride concentrations were higher than sodium, whereas this ratio inverted for locations further away from the Atlantic coast. The observed excess in chloride concentration compared to sodium at our study site means that marine sources have a significant impact on the overall sea salt presence. This influence is also demonstrated by the $\mathrm{Na}^{+} / \mathrm{Cl}^{-}$molar ratios in samples from the MSs along the altitudinal gradient. Higher altitudes are exposed to synoptic circulation and stations there register $\mathrm{Na}^{+} / \mathrm{Cl}^{-}$ratios closer to that in marine air masses. This indicates a gradient of sea salt inputs with relation to terrain height.

Common transport histories were identified on the basis of the PFA. As evinced by their prevalence in the first two components, sodium and chloride concentration are very relevant in both rain and OP. The fact that they exclusively load to factor 1 or 2 , based on their location in multidimensional space, suggests the likely origin of sodium and chloride is sea 
salt from either the Pacific or the Atlantic Ocean. Biomassburning seems to play a minor role in the transport of sodium and chloride, since nitrate and sulfate did not load to the same factor. Although emissions of chloride from fires may be recognizable (Akagi et al., 2011), they are likely irrelevant compared to sea salt (Fabian et al., 2009). Calcium and magnesium (crustal material) loading to factor 2 in OP at TS1 (Table 2) reveals the effect local winds have on emissions at lower elevations. The influence of chloride-containing dust blown from the Loja-Zamora road (Fig. 1) and plumes from local biomass-burning fires are the most likely causes of the high chloride concentrations at ECSF. Findings by Yokouchi et al. (2002), Spanos (2002), Hildemann et al. (1991), Akagi et al. (2011), and Harrison and Pio (1983) substantiate this assumption. According to these studies, chloride not only stems from sea spray but is also emitted from natural and anthropogenic terrestrial sources, i.e. dust, biomass-burning and biogenic forest emissions.

Concluding from the ion concentration time series (Fig. 2) and PFA (Table 2), the distribution of chloride and its sources can differ between valleys and mountain tops. In the former, the concentration is influenced by local winds and emissions, while in the latter the concentration most likely depends on synoptic air-mass transport and emissions from distant sources. This difference in atmospheric circulation between valleys and mountain tops is clearly depicted in Fig. 4, in which only the mountain tops are strongly influenced by the synoptic circulation.

The potential sources defined by PSCF and CWT (Fig. 5) as well as the cluster-concentration statistics (Table 3) concur with the occurrence of the highest sodium and chloride concentration between September and February at the most elevated MSs - El Tiro and Cerro del Consuelo - in the study area (Fig. 2a, b and Table 3). This corroborates the conclusions reached in previous paragraphs that the transport at higher elevations is more synoptically driven. Thus, mediumto long-range transport (reproduced by back-trajectory modelling) has more of an effect in areas of high elevation than at lower slopes and valleys, which are more affected by local transport.

The results of the PSCF and CWT source-receptor models (Fig. 5a, b, c) indicate the areas that contribute to the highest concentration at the receptor site, i.e. the equatorial $\mathrm{Pa}$ cific in the vicinity of the coast of Ecuador and northern Peru as well as the north equatorial Atlantic and the Caribbean Sea. Nonetheless, according to the spatial distribution of the sea salt concentration illustrated in Fig. 8a, the PSCF and CWT models seem to overestimate the contribution of the equatorial Pacific, which exhibits a lower sea salt concentration than the Atlantic Ocean. Analysis of the sea salt concentration along the trajectory clusters reveal a comparable behaviour, wherein the clusters passing over the Pacific contain a lower sea salt concentration. However, the concentration remains quite stable, contrary to the easterly trajectories passing over the continent, where wet scavenging is much more pronounced. Those drier conditions over the equatorial Pacific were clearly seen in DJF, where the concentration among clusters $\mathrm{C} 4, \mathrm{C} 5$, and $\mathrm{C} 6$ even increase as the air masses approach the receptor site (Fig. 7).

The CWT (Fig. 5c) model delivered the best results in that it successfully differentiates the source hot spots over the oceans from those areas of moderate contribution over the continent. In contrast, the PSCF (Fig. 5a, b) is less successful in making this distinction. As already reported by Hsu et al. (2003) and Stohl (1996) a drawback of the PSCF method is that the high and extreme values above a defined threshold get similar probabilities, which hamper their distinction. Thus, PSCF results are heavily influenced by the choice of an arbitrary threshold concentration. Pekney et al. (2006) reported that the selection of the threshold value relies on the evaluated concentration time series. The authors found that for low background values and high concentration peaks, the 90th percentile threshold performs better, while the 75 th percentile is more appropriate for concentration time series with less variability. In our case, the quite strong seasonal variations in the sea salt concentration explain why the PSCF performed better with the 90th percentile threshold (Fig. 5b) rather than the 75 th percentile (Fig. 5a).

To perform a cluster analysis, the trajectories were grouped together and six dominant pathways were identified (C1-C6 in Fig. 6). In general, over the entire observation period, the eastern clusters originating on the equatorial and south equatorial Atlantic predominate $(>51 \%$ of the trajectories). However, when seasonally linking the main transport pathways $(\mathrm{C} 1-\mathrm{C} 6)$ to the sea salt concentration at the receptor site (see Table 3), we notice that those pathways do not have the highest impact on the sea salt concentration in southern Ecuador. Even if easterly and southeasterly transport prevail, larger sea salt loads are transported from the north equatorial Atlantic, the Caribbean Sea, and the equatorial Pacific. The north easterlies originating from the north equatorial Atlantic and Caribbean Sea occurred approximately $29.5 \%$ of the time and accounted for around $56.5 \%$ of the concentration over southern Ecuador. The westerlies from the equatorial Pacific were much less frequent $(\approx 9.3 \%)$ and accounted for $26 \%$ of the concentration. That means, despite the barrier effect of the Andes and the low frequency of occurrences of western pathways, Pacific sea salt sources still play a relevant role in transporting sea salt to the receptor site. Together, equatorial Pacific and north equatorial Atlantic sources accounted for around $82.4 \%$ of the total sea salt concentration. Furthermore, large quantities were added solely from the equatorial Pacific and the Caribbean Sea in a short period of time $(\approx 16 \%$ of trajectories), contributing up to $46.7 \%$ of the total concentration, which stress the importance of these sources to the atmospheric sea salt budget over southern Ecuador.

Nevertheless, in light of the sea salt concentration along the seasonal trajectory clusters (Fig. 7) and sea salt's spatial distribution (Fig. 8a), the significance of Pacific sea salt re- 
Table 4. Comparison of the mean concentration of $\mathrm{Na}^{+}$and $\mathrm{Cl}^{-}$in precipitation in this study with data from other sites in the Amazon basin. The values represent volume-weighted means expressed in $\mu$ eq. $\mathrm{L}^{-1}$.

\begin{tabular}{rlrr}
\hline & $\mathrm{Na}^{+}$ & $\mathrm{Cl}^{-}$ & Reference \\
\hline South Ecuador (RBSF) & 7.80 & 9.60 & This study \\
Central Amazon (Lake Calado) & 2.40 & 4.60 & Williams et al. (1997) \\
Central Amazon (Balbina) & 3.80 & 5.20 & Pauliquevis et al. (2012) \\
Northeast Amazon & 16.60 & 16.90 & Forti et al. (2000) \\
Eastern Amazon (Belem) & 18.90 & 19.50 & Mortatti (1995) \\
\hline
\end{tabular}

mains questionable. The concentration of sea salt in the equatorial Pacific is less than that in the Atlantic. Therefore, the former's influence may be overestimated, even if the concentration decay over the Pacific is much less pronounced as over continental South America. On the one hand, the greater frequency of the north easterlies, and on the other hand, the higher sea salt concentration in the Atlantic are good reasons that justify a greater influence of the Caribbean Sea and the north equatorial Atlantic with respect to the atmospheric sea salt budget over southern Ecuador.

Regarding the addition of salt from biomass burning to the chloride budget at the study area, based on the co-occurrence of high $\mathrm{NO}_{x}$ concentration from biomass burning and high sea salt concentration during the main sea salt transport season (SON and DJF, in Figs. 8a and 9), it is very likely that sea salt is indeed enriched by biomass-burning chloride. However, this assumption is not corroborated by our field samples from southern Ecuador. In the concentration of sodium and chloride from rain and OP samples we did not find any correlation between nitrate and sulfate, the products of biomass burning (Fabian et al., 2009; Makowski Giannoni et al., 2013, 2014), and sodium and chloride (Table 2). Furthermore, the mass fraction of biomass-burning sodium (maximum $0.07 \%$ ) and chloride (maximum values in the order of $3.5 \%$, see Fig. 8b) are very small and therefore play only a limited role in the sodium and chloride transport to south Ecuador.

\section{Conclusions}

Sodium and chloride ions exhibited different concentrations in rain and OP along the altitudinal gradient of interest to this study. Their concentration levels and temporal variability in the highest and more exposed MSs presented a stronger seasonality linked to global circulation patterns, and thus a greater influence from sea salt, confirmed by $\mathrm{Na}^{+} / \mathrm{Cl}^{-}$molar ratios similar to those from marine air masses. Similar seasonal patterns were observed by modelling at a larger scale, using MACC sea salt concentration data and ERAInterim air mass back trajectories, confirming the influence of the medium- to long-range transport at higher elevations. In contrast, MSs situated at lower altitudes were influenced by the mountain-valley wind systems and local aerosols.
According the sea salt transport analysis by backtrajectory modelling for medium- to long-range sources, the Caribbean Sea, the north equatorial Atlantic, and equatorial Pacific play an important role in the transport of sea salt to southern Ecuador. Here, the Caribbean and north equatorial Atlantic sources have the greatest impact. Equatorial Pacific sources, on the other hand, are less significant: they are seasonally driven with the greatest contributions occurring when the ITCZ migrates further south in austral late spring (SON) and summer (DJF). In total, the north equatorial Atlantic and equatorial Pacific contribute to 56.5 and $26 \%$ of the total concentration in southern Ecuador, respectively, which represents an important addition to the total atmospheric sea salt budget.

A comparison of the sodium and chloride concentrations at our area of investigation with those at other sites further east substantiates the important role played by the identified sources (Caribbean Sea, north equatorial Atlantic, and equatorial Pacific oceans) on the sea salt transport to our study area (Table 4). Even if concentrations in southern Ecuador are lower than in forests close to the Atlantic, they clearly exceed those concentrations measured in the central Brazilian Amazon thousands of kilometres to the east, despite being located further from the Atlantic coast. However, whether the higher sodium and chloride availability observed in southern Ecuador makes this tropical ecosystem less salt deprived than other similar ecosystems in the western Amazon is still an open question deserving of investigation.

\section{Data availability}

The MACC sea salt and biomass-burning $\mathrm{NO}_{x}$ fluxes are available at http://apps.ecmwf.int/datasets/data/ macc-reanalysis/levtype $=\mathrm{ml} /$ and http://apps.ecmwf.int/ datasets/data/cams-gfas/, respectively. The ERA Interim reanalysis data can be accessed at http://apps.ecmwf. int/datasets/data/interim-full-daily/levtype=sfc/. The precipitation chemistry data and climate data from in-situ meteorological stations are accessible at the Platform for Biodiversity and Ecosystem Monitoring and Research in South Ecuador: http://www.tropicalmountainforest.org/ data_pre.do?cmd=showall. 


\section{Appendix A: Tables}

Table A1. The 6-year average ion concentration (2004-2009) in rain and OP, precipitation volume, and electrical conductivity at MSs along an altitudinal gradient in southern Ecuador.

\begin{tabular}{|c|c|c|c|c|c|c|c|c|c|c|c|c|c|c|}
\hline Site & Collector & $\begin{array}{r}\text { Elev. } \\
(\mathrm{m})\end{array}$ & $\begin{array}{r}\mathrm{P} \\
(\mathrm{mm})\end{array}$ & $\mathrm{pH}$ & $\begin{array}{r}\mathrm{eC} \\
\left(\mu \mathrm{S} \mathrm{cm}^{-1}\right)\end{array}$ & $\mathrm{NH}_{4}{ }^{-}$ & $\mathrm{Ca}^{+}$ & $\mathrm{Cl}^{-}$ & $\mathrm{PO}_{4}^{-}$ & $\begin{array}{c}\mathrm{Mg}^{+} \\
\left(\mathrm{mg} \mathrm{L}^{-1}\right)\end{array}$ & $\mathrm{NO}_{3}{ }^{-}$ & $\mathrm{K}^{+}$ & $\mathrm{Na}^{+}$ & $\mathrm{SO}_{4}^{-}$ \\
\hline C. del Consuelo & $\mathrm{OP}$ & 3180 & 105.59 & 5.4 & 12 & 0.55 & 0.17 & 0.42 & 0.085 & 0.059 & 0.82 & 0.15 & 0.22 & 1 \\
\hline ECSF & $\mathrm{OP}$ & 1960 & 7.26 & 5 & 13 & 0.17 & 0.42 & 0.86 & 0.098 & 0.073 & 0.14 & 0.23 & 0.22 & 0.44 \\
\hline ECSF & Rain & 1960 & 142.48 & 5.3 & 4.3 & 0.15 & 0.11 & 0.43 & 0.13 & 0.048 & 0.077 & 0.16 & 0.18 & 0.24 \\
\hline El Tiro & $\mathrm{OP}$ & 2825 & 75.41 & 6 & 20 & 0.8 & 0.19 & 0.45 & 0.12 & 0.07 & 1.4 & 0.3 & 0.31 & 1.6 \\
\hline El Tiro & Rain & 2825 & 142.37 & 5.4 & 5.4 & 0.22 & 0.14 & 0.36 & 0.15 & 0.047 & 0.12 & 0.15 & 0.24 & 0.39 \\
\hline TS1 & $\mathrm{OP}$ & 2660 & 34.15 & 5.3 & 5.2 & 0.25 & 0.12 & 0.5 & 0.16 & 0.054 & 0.16 & 0.12 & 0.25 & 0.32 \\
\hline TS1 & Rain & 2660 & 279 & 5.4 & 4 & 0.18 & 0.077 & 0.36 & 0.13 & 0.047 & 0.084 & 0.13 & 0.18 & 0.26 \\
\hline
\end{tabular}


Acknowledgements. We thank the German Academic Exchange Service (DAAD) for funding the $\mathrm{PhD}$ thesis of S. Makowski Giannoni (ref. no. A/08/98222) and the German Research Foundation (DFG) for funding this work in the scope of the Research Unit RU816 (funding no. BE 1780/15-1). We also thank Thorsten Peters for providing meteorological data. We are grateful to Giulia F. Curatola Fernández and Tim Appelhans for their valuable help. We also thank the foundation Nature \& Culture International (NCI) Loja and San Diego for logistic support. Last but not least we are very thankful to Jeffrey Reid from the U.S. Naval Research Laboratory for his valuable comments on the manuscript.

Edited by: R. Krejci

Reviewed by: J. Reid and two anonymous referees

\section{References}

Akagi, S. K., Yokelson, R. J., Wiedinmyer, C., Alvarado, M. J., Reid, J. S., Karl, T., Crounse, J. D., and Wennberg, P. O.: Emission factors for open and domestic biomass burning for use in atmospheric models, Atmos. Chem. Phys., 11, 4039-4072, doi:10.5194/acp-11-4039-2011, 2011.

Beck, E., Bendix, J., Kottke, I., Makeschin, F., and Mosandl, R. (Eds.): Gradients in a tropical mountain ecosystem of Ecuador, vol. 198 of Ecological Studies, Springer Berlin/Heidelberg, Berlin, Germany, doi:10.1007/978-3-540-73526-7, 2008.

Bendix, J., Rollenbeck, R., and Reudenbach, C.: Diurnal patterns of rainfall in a tropical Andean valley of southeastern Ecuador as seen by a vertically pointing $\mathrm{K}$-band Doppler radar, Int. J. Climatol., 26, 829-846, doi:10.1002/joc.1267, 2006.

Bendix, J., Rollenbeck, R., Goettlicher, D., Nauss, T., and Fabian, P.: Seasonality and diurnal pattern of very low clouds in a deeply incised valley of the eastern tropical Andes (South Ecuador) as observed by a cost-effective WebCam system, Meteorol. Appl., 15, 281-291, doi:10.1002/met, 2008a.

Bendix, J., Rollenbeck, R., Richter, M., Fabian, P., and Emck, P.: Climate, in: Gradients in a Tropical Mountain Ecosystem of Ecuador, edited by: Beck, E., Bendix, J., Kottke, I., Makeschin, F., and Mosandl, R., chap. 1, Springer Berlin/Heidelberg, ecological Edn., 63-74, doi:10.1007/978-3-540-73526-7_8, 2008b.

Bendix, J., Beck, E., Brauning, A., Makeschin, F., Mosandl, R., Scheu, S., and Wilcke, W. (Eds.): Ecosystem services, biodiversity and environmental change in a tropical mountain ecosystem of South Ecuador, vol. xxx, Springer, Berlin-Heidelberg, doi:10.1007/978-3-642-38137-9, 2013.

Benedetti, a., Morcrette, J.-J., Boucher, O., Dethof, A., Engelen, R. J., Fisher, M., Flentje, H., Huneeus, N., Jones, L., Kaiser, J. W., Kinne, S., Mangold, a., Razinger, M., Simmons, A. J., and Suttie, M.: Aerosol analysis and forecast in the European Centre for Medium-Range Weather Forecasts Integrated Forecast System: 2. Data assimilation, J. Geophys. Res., 114, D13205, doi:10.1029/2008JD011115, 2009.

Bobbink, R., Hicks, K., and Galloway, J.: Global assessment of nitrogen deposition effects on terrestrial plant diversity: a synthesis, Ecol. Appl., 20, 30-59, doi:10.1890/08-1140.1, 2010.

Carslaw, D. C. and Ropkins, K.: openair - An R package for air quality data analysis, Environ. Modell. Softw., 27-28, 52-61, doi:10.1016/j.envsoft.2011.09.008, 2012.
Clarke, N., Zlindra, D., Ulrich, E., Mosello, R., Derome, J., Derome, K., König, N., Lövblad, G., Draaijers, G., Hansen, K., Thimonier, A., and Waldner, P.: sampling and analysis of deposition: Part XIV, in: Manual on methods and criteria for harmonized sampling, assessment, monitoring and analysis of the effects of air pollution on forests., chap. 14, UNECE, ICP Forests, Hamburg, available at: http://icp-forests.net/page/ icp-forests-manual (last access: 8 August 2016), 2010.

Dee, D. P., Uppala, S. M., Simmons, A. J., Berrisford, P., Poli, P., Kobayashi, S., Andrae, U., Balmaseda, M. A., Balsamo, G., Bauer, P., Bechtold, P., Beljaars, A. C. M., van de Berg, L., Bidlot, J., Bormann, N., Delsol, C., Dragani, R., Fuentes, M., Geer, A. J., Haimberger, L., Healy, S. B., Hersbach, H., Hólm, E. V., Isaksen, L., Kållberg, P., Köhler, M., Matricardi, M., McNally, A. P., Monge-Sanz, B. M., Morcrette, J.-J., Park, B.-K., Peubey, C., de Rosnay, P., Tavolato, C., Thépaut, J.-N., and Vitart, F.: The ERA-Interim reanalysis: configuration and performance of the data assimilation system, Q. J. Roy. Meteor. Soc., 137, 553-597, doi:10.1002/qj.828, 2011.

Dentener, F., Drevet, J., Lamarque, J. F., Bey, I., Eickhout, B., Fiore, a. M., Hauglustaine, D., Horowitz, L. W., Krol, M., Kulshrestha, U. C., Lawrence, M., Galy-Lacaux, C., Rast, S., Shindell, D., Stevenson, D., Van Noije, T., Atherton, C., Bell, N., Bergman, D., Butler, T., Cofala, J., Collins, B., Doherty, R., Ellingsen, K., Galloway, J., Gauss, M., Montanaro, V., Müller, J. F., Pitari, G., Rodriguez, J., Sanderson, M., Solmon, F., Strahan, S., Schultz, M., Sudo, K., Szopa, S., and Wild, O.: Nitrogen and sulfur deposition on regional and global scales: A multimodel evaluation, Global Biogeochem. Cy., 20, GB4003, doi:10.1029/2005GB002672, 2006.

Draxler, R. and Hess, G.: An overview of the HYSPLIT_4 modeling system of trajectories, dispersion, and deposition, Aust. Meteorol. Mag., 47, 295-308, 1998.

Dudley, R., Kaspari, M., and Yanoviak, S. P.: Lust for Salt in the Western Amazon, Biotropica, 44, 6-9, doi:10.1111/j.17447429.2011.00818.x, 2012.

Emck, P.: A climatology of South Ecuador, Phd thesis, University of Erlangen, available at: http://www.opus.ub.uni-erlangen. de/opus/volltexte/2007/656/ (last access: 8 August 2016), 2007.

Fabian, P., Rollenbeck, R., Spichtinger, N., Brothers, L., Dominguez, G., and Thiemens, M.: Sahara dust, ocean spray, volcanoes, biomass burning: pathways of nutrients into Andean rainforests, Adv. Geosci., 22, 85-94, doi:10.5194/adgeo-22-852009, 2009.

Ferek, R. J., Reid, J. S., Hobbs, P. V., Blake, D. R., and Liousse, C.: Emission factors of hydrocarbons, halocarbons, trace gases and particles from biomass burning in Brazil, J. Geophys. Res.Atmos., 103, 32107-32118, doi:10.1029/98JD00692, 1998.

Fleming, Z. L., Monks, P. S., and Manning, A. J.: Review: Untangling the influence of air-mass history in interpreting observed atmospheric composition, Atmos. Res., 104-105, 1-39, doi:10.1016/j.atmosres.2011.09.009, 2012.

Forti, M. C., Melfi, A. J., Astolfo, R., and Fostier, A.-H.: Rainfall chemistry composition in two ecosystems in the northeastern Brazilian Amazon (Amapá State), J. Geophys. Res., 105, 28895, doi:10.1029/2000JD900235, 2000.

Galloway, J. N., Townsend, A. R., Erisman, J. W., Bekunda, M., Cai, Z., Freney, J. R., Martinelli, L. A., Seitzinger, S. P., and Sutton, M. A.: Transformation of the nitrogen cycle: recent trends, ques- 
tions, and potential solutions, Science (New York, N.Y.), 320, 889-892, doi:10.1126/science.1136674, 2008.

Griffith, K. T., Ponette-González, A. G., Curran, L. M., and Weathers, K. C.: Assessing the influence of topography and canopy structure on Douglas fir throughfall with LiDAR and empirical data in the Santa Cruz mountains, USA, Environ. Monitor. Assess., 187, 4486, doi:10.1007/s10661-015-4486-6, 2015.

Guelle, W., Schulz, M., Balkanski, Y., and Dentener, F.: Influence of the source formulation on modeling the atmospheric global distribution of sea salt aerosol, J. Geophys. Res., 106, 27509, doi:10.1029/2001JD900249, 2001.

Harrison, R. M. and Pio, C. A.: Major ion composition and chemical associations of inorganic atmospheric aerosols., Environ. Sci. Technol., 17, 169-174, doi:10.1021/es00109a009, 1983.

Hildemann, L. M., Markowski, G. R., and Cass, G. R.: Chemical composition of emissions from urban sources of fine organic aerosol, Environ. Sci. Technol., 25, 744-759, doi:10.1021/es00016a021, 1991.

Homeier, J., Hertel, D., Camenzind, T., Cumbicus, N. L., Maraun, M., Martinson, G. O., Poma, L. N., Rillig, M. C., Sandmann, D., Scheu, S., Veldkamp, E., Wilcke, W., Wullaert, H., and Leuschner, C.: Tropical andean forests are highly susceptible to nutrient inputs-rapid effects of experimental $\mathrm{N}$ and $\mathrm{p}$ addition to an ecuadorian montane forest., PloS one, 7, e47128, doi:10.1371/journal.pone.0047128, 2012.

Hsu, Y.-K., Holsen, T. M., and Hopke, P. K.: Comparison of hybrid receptor models to locate $\mathrm{PCB}$ sources in Chicago, Atmos. Environ., 37, 545-562, doi:10.1016/S1352-2310(02)00886-5, 2003.

Inness, A., Baier, F., Benedetti, A., Bouarar, I., Chabrillat, S., Clark, H., Clerbaux, C., Coheur, P., Engelen, R. J., Errera, Q., Flemming, J., George, M., Granier, C., Hadji-Lazaro, J., Huijnen, V., Hurtmans, D., Jones, L., Kaiser, J. W., Kapsomenakis, J., Lefever, K., Leitão, J., Razinger, M., Richter, A., Schultz, M. G., Simmons, A. J., Suttie, M., Stein, O., Thépaut, J.-N., Thouret, V., Vrekoussis, M., Zerefos, C., and the MACC team: The MACC reanalysis: an 8 yr data set of atmospheric composition, Atmos. Chem. Phys., 13, 4073-4109, doi:10.5194/acp-13-4073-2013, 2013.

Jaeglé, L., Quinn, P. K., Bates, T. S., Alexander, B., and Lin, J.-T.: Global distribution of sea salt aerosols: new constraints from in situ and remote sensing observations, Atmos. Chem. Phys., 11, 3137-3157, doi:10.5194/acp-11-3137-2011, 2011.

Kaiser, J. W., Heil, A., Andreae, M. O., Benedetti, A., Chubarova, N., Jones, L., Morcrette, J.-J., Razinger, M., Schultz, M. G., Suttie, M., and van der Werf, G. R.: Biomass burning emissions estimated with a global fire assimilation system based on observed fire radiative power, Biogeosciences, 9, 527-554, doi:10.5194/bg-9-527-2012, 2012.

Kaspari, M., Yanoviak, S. P., and Dudley, R.: On the biogeography of salt limitation: a study of ant communities., P. Natl. Acad. Sci. USA, 105, 17848-17851, doi:10.1073/pnas.0804528105, 2008.

Kaspari, M., Yanoviak, S. P., Dudley, R., Yuan, M., and Clay, N. A.: Sodium shortage as a constraint on the carbon cycle in an inland tropical rainforest, P. Natl. Acad. Sci. USA, 106, 19405-19409, doi:10.1073/pnas.0906448106, 2009.

Keene, W. C., Pszenny, A. A. P., Galloway, J. N., and Hawley, M. E.: Sea-salt corrections and interpretation of constituent ratios in marine precipitation, J. Geophys. Res., 91, 6647, doi:10.1029/JD091iD06p06647, 1986.
Kirchner, M., Fegg, W., Römmelt, H., Leuchner, M., Ries, L., Zimmermann, R., Michalke, B., Wallasch, M., Maguhn, J., FausKessler, T., and Jakobi, G.: Nitrogen deposition along differently exposed slopes in the Bavarian Alps., Sci. Total Environ., 470471, 895-906, doi:10.1016/j.scitotenv.2013.10.036, 2014.

Koehler, B., Corre, M. D., Veldkamp, E., Wullaert, H., and Wright, S. J.: Immediate and long-term nitrogen oxide emissions from tropical forest soils exposed to elevated nitrogen input, Glob. Change Biol., 15, 2049-2066, doi:10.1111/j.13652486.2008.01826.x, 2009.

Lee, A. T. K., Kumar, S., Brightsmith, D. J., and Marsden, S. J.: Parrot claylick distribution in South America: do patterns of "where" help answer the question "why"?, Ecography, 33, 503513, doi:10.1111/j.1600-0587.2009.05878.x, 2009.

Lizcano, D. J. and Cavelier, J.: Características Químicas de salados y hábitos alimenticios de la Danta de montaña (Tapirus pinchaque Roulin, 1829) en los Andes Centrales de Colombia, Mastozoología neotropical, 11, 193-201, 2004.

Lovett, G. and Kinsman, J.: Atmospheric pollutant deposition to high-elevation ecosystems, Atmos. Environ., 24, 2767-2786, 1990.

Mahowald, N. M., Artaxo, P., Baker, A. R., Jickells, T. D., Okin, G. S., Randerson, J. T., and Townsend, A. R.: Impacts of biomass burning emissions and land use change on Amazonian atmospheric phosphorus cycling and deposition, Global Biogeochem. Cy., 19, doi:10.1029/2005GB002541, 2005.

Makowski Giannoni, S., Rollenbeck, R., Fabian, P., and Bendix, J.: Complex topography influences atmospheric nitrate deposition in a neotropical mountain rainforest, Atmos. Environ., 79, 385394, doi:10.1016/j.atmosenv.2013.06.023, 2013.

Makowski Giannoni, S., Rollenbeck, R., Trachte, K., and Bendix, J.: Natural or anthropogenic? On the origin of atmospheric sulfate deposition in the Andes of southeastern Ecuador, Atmos. Chem. Phys., 14, 11297-11312, doi:10.5194/acp-14-112972014, 2014.

Malm, W. C., Johnson, C. E., and Bresch, J. F.: Application of principal component analysis for purposes of identifying sourcereceptor relationships, in: Receptor methods for source apportionment, edited by: Pace, T. G., Air pollution control association, Pittsburgh, PA, 1986.

Matson, A. L., Corre, M. D., and Veldkamp, E.: Nitrogen cycling in canopy soils of tropical montane forests responds rapidly to indirect $\mathrm{N}$ and $\mathrm{P}$ fertilization., Glob. Change Biol., 20, 3802 3813, doi:10.1111/gcb.12668, 2014.

Matson, P., Lohse, K. A., and Hall, S. J.: The Globalization of Nitrogen Deposition: Consequences for Terrestrial Ecosystems, AMBIO A J. Hum. Environ., 31, 113-119, doi:10.1579/0044-744731.2.113, 2002.

Millero, F.: Treatise on Geochemistry, Elsevier, doi:10.1016/B9780-08-095975-7.00601-X, 2014.

Morcrette, J.-J., Boucher, O., Jones, L., Salmond, D., Bechtold, P., Beljaars, A., Benedetti, A., Bonet, A., Kaiser, J. W., Razinger, M., Schulz, M., Serrar, S., Simmons, A. J., Sofiev, M., Suttie, M., Tompkins, A. M., and Untch, A.: Aerosol analysis and forecast in the European Centre for Medium-Range Weather Forecasts Integrated Forecast System: Forward modeling, J. Geophys. Res., 114, D06206, doi:10.1029/2008JD011235, 2009.

Mortatti, J.: Erosão na Amazonia: processos. Modelos e balanço, Phd thesis, São Paulo, Brazil, 1995. 
Pauliquevis, T., Lara, L. L., Antunes, M. L., and Artaxo, P.: Aerosol and precipitation chemistry measurements in a remote site in Central Amazonia: the role of biogenic contribution, Atmos. Chem. Phys., 12, 4987-5015, doi:10.5194/acp-12-4987-2012, 2012.

Pekney, N. J., Davidson, C. I., Zhou, L., and Hopke, P. K.: Application of PSCF and CPF to PMF-Modeled Sources of PM 2.5 in Pittsburgh, Aerosol Sci. Technol., 40, 952-961, doi:10.1080/02786820500543324, 2006.

Peñuelas, J., Poulter, B., Sardans, J., Ciais, P., van der Velde, M., Bopp, L., Boucher, O., Godderis, Y., Hinsinger, P., Llusia, J., Nardin, E., Vicca, S., Obersteiner, M., and Janssens, I. A.: Human-induced nitrogen-phosphorus imbalances alter natural and managed ecosystems across the globe., Nat. Commun., 4, 2934, doi:10.1038/ncomms3934, 2013.

Pett-Ridge, J. C.: Contributions of dust to phosphorus cycling in tropical forests of the Luquillo Mountains, Puerto Rico, Biogeochemistry, 94, 63-80, doi:10.1007/s10533-009-9308-x, 2009.

Phoenix, G. K., Hicks, K. W., Cinderby, S., Kuylenstierna, J. C. I., Stock, W. D., Dentener, F. J., Giller, K. E., Austin, A. T., Lefroy, R. D. B., Gimeno, B. S., Ashmore, M. R., and Ineson, P.: Atmospheric nitrogen deposition in world biodiversity hotspots: the need for a greater global perspective in assessing $\mathrm{N}$ deposition impacts, Glob. Change Biol., 12, 470-476, doi:10.1111/j.13652486.2006.01104.x, 2006.

Powell, L. L., Powell, T. U., Powell, G. V. N., and Brightsmith, D. J.: Parrots Take it with a Grain of Salt: Available Sodium Content May Drive Collpa (Clay Lick) Selection in Southeastern Peru, Biotropica, 41, 279-282, doi:10.1111/j.17447429.2009.00514.x, 2009.

Pozzer, A., de Meij, A., Pringle, K. J., Tost, H., Doering, U. M., van Aardenne, J., and Lelieveld, J.: Distributions and regional budgets of aerosols and their precursors simulated with the EMAC chemistry-climate model, Atmos. Chem. Phys., 12, 961-987, doi:10.5194/acp-12-961-2012, 2012.

Reid, J. S., Prins, E. M., Westphal, D. L., Schmidt, C. C., Richardson, K. A., Christopher, S. A., Eck, T. F., Reid, E. A., Curtis, C. A., and Hoffman, J. P.: Real-time monitoring of South American smoke particle emissions and transport using a coupled remote sensing/box-model approach, Geophys. Res. Lett., 31, L06107, doi:10.1029/2003GL018845, 2004.

Richter, M., Beck, E., Rollenbeck, R., and Bendix, J.: The study area, in: Ecosystemservices, biodiversity and environmental change in a tropical mountain ecosystem of South Ecuador, edited by: Bendix, J., Beck, E., Brauning, A., Makeschin, F., Mosandl, R., Scheu, S., and Wilcke, W., chap. 1, Springer Berlin/Heidelberg, Berlin, Germany, doi:10.1007/978-3-64238137-9_1, 2013.

Riuttanen, L., Hulkkonen, M., Dal Maso, M., Junninen, H., and Kulmala, M.: Trajectory analysis of atmospheric transport of fine particles, $\mathrm{SO}_{2}, \mathrm{NO}_{x}$ and $\mathrm{O}_{3}$ to the SMEAR II station in Finland in 1996-2008, Atmos. Chem. Phys., 13, 2153-2164, doi:10.5194/acp-13-2153-2013, 2013.

Robinson, N. H., Newton, H. M., Allan, J. D., Irwin, M., Hamilton, J. F., Flynn, M., Bower, K. N., Williams, P. I., Mills, G., Reeves, C. E., McFiggans, G., and Coe, H.: Source attribution of Bornean air masses by back trajectory analysis during the OP3 project, Atmos. Chem. Phys., 11, 9605-9630, doi:10.5194/acp-11-9605$2011,2011$.
Rollenbeck, R., Bendix, J., Fabian, P., Boy, J., Wilcke, W., Dalitz, H., Oesker, M., and Emck, P.: Comparison of different techniques for the measurement of precipitation in tropical montane rain forest regions, J. Atmos. Ocean. Tech., 24, 156-168, doi:10.1175/JTECH1970.1, 2007.

Rollenbeck, R., Bendix, J., and Fabian, P.: Spatial and temporal dynamics of atmospheric water inputs in tropical mountain forests of South Ecuador, Hydrol. Process., 25, 344-352, doi:10.1002/hyp.7799, 2011.

Schemenauer, R. S. and Cereceda, P.: A proposed standard fog collector for use in high-elevation regions, J. Appl. Meteorol., 33, 1313-1322, 1994.

Schulz, M., de Leeuw, G., and Balkanski, Y.: Sea-salt aerosol source functions and emissions, in: Emissions of Atmospheric Trace Compounds, Springer Netherlands, 333-359, doi:10.1007/9781-4020-2167-1_9, 2004.

Seibert, P., Kromb-Kolb, H., Baltensperger, U., Jost, D., and Schwikowski, M.: Trajectory analysis of high-alpine air pollution data, in: NATO challenges of modern society, edited by: Gryning, S.-E. and Millán, M. M., . Springer US, 595-596, doi:10.1007/978-1-4615-1817-4_65, 1994.

Spanos, T.: Environmetric modeling of emission sources for dry and wet precipitation from an urban area, Talanta, 58, 367-375, doi:10.1016/S0039-9140(02)00285-0, 2002.

Stohl, A.: Trajectory statistics-A new method to establish sourcereceptor relationships of air pollutants and its application to the transport of particulate sulfate in Europe, Atmos. Environ., 30, 579-587, doi:10.1016/1352-2310(95)00314-2, 1996.

Talbot, R. W., Andreae, M. O., Berresheim, H., Artaxo, P., Garstang, M., Harriss, R. C., Beecher, K. M., and Li, S. M.: Aerosol Chemistry During the Wet Season in Central Amazonia: The Influence of Long-Range Transport, J. Geophys. Res., 95, 16955-16969, 1990.

Tanner, E. V. J., Vitousek, P. M., and Cuevas, E.: Experimental investigation of nutrient limitation of forest growth on wet tropical mountains, Ecology, 79, 10-22, doi:10.1890/00129658(1998)079[0010:EIONLO]2.0.CO;2, 1998.

Tardy, Y., Bustillo, V., Roquin, C., Mortatti, J., and Victoria, R.: The Amazon. Bio-geochemistry applied to river basin management, Appl. Geochem., 20, 1746-1829, doi:10.1016/j.apgeochem.2005.06.001, 2005.

Tipping, E., Benham, S., Boyle, J. F., Crow, P., Davies, J., Fischer, U., Guyatt, H., Helliwell, R., Jackson-Blake, L., Lawlor, A. J., Monteith, D. T., Rowe, E. C., and Toberman, H.: Atmospheric deposition of phosphorus to land and freshwater., Environ. Sci. Process. Impacts, 16, 1608-1617, doi:10.1039/c3em00641g, 2014.

Vet, R., Artz, R. S., Carou, S., Shaw, M., Ro, C.-U., Aas, W., Baker, A., Bowersox, V. C., Dentener, F., Galy-Lacaux, C., Hou, A., Pienaar, J. J., Gillett, R., Forti, M. C., Gromov, S., Hara, H., Khodzher, T., Mahowald, N. M., Nickovic, S., Rao, P., and Reid, N. W.: A global assessment of precipitation chemistry and deposition of sulfur, nitrogen, sea salt, base cations, organic acids, acidity and $\mathrm{pH}$, and phosphorus, Atmos. Environ., 93, 3-100, doi:10.1016/j.atmosenv.2013.10.060, 2014.

Vitousek, P. M.: Litterfall, Nutrient Cycling, and Nutrient Limitation in Tropical Forests, 65, 285-298, 1984.

Voigt, C. C., Capps, K. A., Dechmann, D. K. N., Michener, R. H., and Kunz, T. H.: Nutrition or detoxification: why bats visit 
mineral licks of the Amazonian rainforest, PloS one, 3, e2011, doi:10.1371/journal.pone.0002011, 2008.

Wang, F., Li, J., Wang, X., Zhang, W., Zou, B., Neher, D. A., and Li, Z.: Nitrogen and phosphorus addition impact soil $\mathrm{N}_{2} \mathrm{O}$ emission in a secondary tropical forest of South China, Scientific reports, 4, 5615, doi:10.1038/srep05615, 2014.

Wilcke, W., Leimer, S., Peters, T., Emck, P., Rollenbeck, R., Trachte, K., Valarezo, C., and Bendix, J.: The nitrogen cycle of tropical montane forest in Ecuador turns inorganic under environmental change, Global Biogeochem. Cy., 27, 1194-1204, doi:10.1002/2012GB004471, 2013.

Williams, M. R., Fisher, T. R., and Melack, J. M.: Chemical composition and deposition of rain in the central Amazon, Brazil, Atmos. Environ., 31, 207-217, doi:10.1016/1352-2310(96)00166$5,1997$.

Wolf, K., Veldkamp, E., Homeier, J., and Martinson, G. O.: Nitrogen availability links forest productivity, soil nitrous oxide and nitric oxide fluxes of a tropical montane forest in southern Ecuador, Global Biogeochem. Cy., 25, GB4009, doi:10.1029/2010GB003876, 2011.
Wullaert, H., Geographie, P., Chemie, F., and Gutenberg-universit, J.: Response of nutrient cycles of an old-growth montane forest in Ecuador to experimental low-level nutrient amendments, $\mathrm{PhD}$ thesis, available at: http://ubm.opus.hbz-nrw.de/volltexte/2010/ 2312/ (last access: 8 August 2016), 2010.

Yokouchi, Y., Ikeda, M., Inuzuka, Y., and Yukawa, T.: Strong emission of methyl chloride from tropical plants, Nature, 416, 163165, doi:10.1038/416163a, 2002.

Yu, H., Chin, M., Yuan, T., Bian, H., Remer, L. A., Prospero, J. M., Omar, A., Winker, D., Yang, Y., Zhang, Y., Zhang, Z., and Zhao, C.: The Fertilizing Role of African Dust in the Amazon Rainforest: A First Multiyear Assessment Based on CALIPSO Lidar Observations, Geophys. Res. Lett., 42, 1984 1991, doi:10.1002/2015GL063040, 2015.

Zeng, Y. and Hopke, P.: A study of the sources of acid precipitation in Ontario, Canada, Atmos. Environ., 23, 1499-1509, doi:10.1016/0004-6981(89)90409-5, 1989. 